\title{
Soils of Amazonia with particular reference to the RAINFOR sites
}

\author{
C. A. Quesada ${ }^{1,2}$, J. Lloyd ${ }^{1,3}$, L. O. Anderson ${ }^{4}$, N. M. Fyllas ${ }^{1}$, M. Schwarz ${ }^{5, *}$, and C. I. Czimczik ${ }^{5, * *}$ \\ ${ }^{1}$ School of Geography, University of Leeds, LS2 9JT, UK \\ ${ }^{2}$ Institito Nacional de Pesquisas da Amazônia, Avenida André Araújo, 2936, Aleixo, CEP 69060-001, Manaus-AM, Brazil \\ ${ }^{3}$ School of Earth and Environmental Sciences, James Cook University, Cairns, Qld 4878, Australia \\ ${ }^{4}$ School of Geography and the Environment, University of Oxford, South Parks Road, Oxford, OX1 3QY, UK \\ ${ }^{5}$ Max-Planck-Institut fuer Biogeochemie, Postfach 100164, 07701, Jena, Germany \\ *now at: Fieldwork Assistance, Postfach 101022, 07710 Jena, Germany \\ ** now at: Department of Earth System Science, University of California, 2103 Croul Hall, Irvine, CA, 92697-3100, USA
}

Received: 18 December 2008 - Published in Biogeosciences Discuss.: 8 April 2009

Revised: 9 March 2011 - Accepted: 6 May 2011 - Published: 1 June 2011

\begin{abstract}
The tropical forests of the Amazon Basin occur on a wide variety of different soil types reflecting a rich diversity of geologic origins and geomorphic processes. We here review the existing literature about the main soil groups of Amazonia, describing their genesis, geographical patterns and principal chemical, physical and morphologic characteristics. Original data is also presented, with profiles of exchangeable cations, carbon and particle size fraction illustrated for the principal soil types; also emphasizing the high diversity existing within the main soil groups when possible. Maps of geographic distribution of soils occurring under forest vegetation are also introduced, and to contextualize soils into an evolutionary framework, a scheme of soil development is presented having as its basis a chemical weathering index. We identify a continuum of soil evolution in Amazonia with soil properties varying predictably along this pedogenetic gradient.
\end{abstract}

\section{Introduction}

Tropical soils can arise from a wide variety of parent materials, climatic conditions, biotic interactions, landforms, geomorphic elements and soil age. Many of these factors vary more widely in the tropics than in the temperate zone (Sanchez, 1976; Richter and Babbar, 1991). Amazonia comprises a vast and heterogeneous region, with many of these factors, especially parent materials; landforms, geology and geomorphologic history varying widely (Sombroek, 1966,
2000; Irion, 1978). On the other hand, factors such as soil temperature and soil moisture regimes are common to many Amazonian soils (Sanchez, 1976; van Wambeke, 1978). In the early days of soil science in this region, Marbut and Manifold (1926) observed at least six different groups of soils occurring commonly in the region, suggesting that many soils occurring in the tropics had little or no morphological difference to those observed in the temperate zone. A subsequent view did then, however, emerge that tropical soils are invariably ancient, lateritic and intensively weathered. Although this view persists to some extent even to the current day, both Sanchez (1976) and Richter and Babbar (1991) demonstrated that tropical soils are actually very diverse, encompassing all different taxa, from the lowest to the highest pedogenic levels. Indeed, by that time Sanchez and Buol (1975) had already found that soils previously mapped as Ferralsols in the Peruvian Amazon actually were Ultisols, Alfisols and Inceptsols (Acrisols, Luvisols/Lixisols and Cambisols in the World Reference Base soil classification system: IUSS Working Group WRB, 2006), suggesting that ancient Ferralsols may actually be confined to areas of the Guyana and Brazilian shields. Sombroek (1966) also reported a large diversity of soils in his studies of the Brazilian Amazon, describing a high diversity of "latosols", "kaolinitic latossolic sands", "podzols", "lithosols", ground water laterites, hydromorphic grey podzolics, "Regosols", Gleysols, saline and alkali soils, Indian black earths and terras roxas estruturadas (equivalent to present day Nitisols) plus other minor and uncommon soil groups not properly identified. 
Richter and Babbar (1991) gave an analysis of available soil surveys up to that time, comparing results from the FAO World Soil Map (1988) and the Brazilian Soil Survey for Amazonia (EMBRAPA, 1981), also giving estimated coverage areas for each different soil order. They estimated that Ferralsols covered 0.391 of Brazilian Amazonia, with Acrisols covering 0.323, Gleysols and Plinthosols 0.063 and 0.069 respectively, and with Arenosols covering 0.044, Leptosols 0.045, Podzols 0.028, and Cambisols 0.013 of the area with Fluvisols and Nitisols covering less than 0.010. They also indicated that there was a considerable bias towards the dominance of Ferralsols in the FAO map which was related to the methodology used by the FAO system; Ferralsols being mapped on the basis of estimates of climate and vegetation data instead of empirical soil analysis.

Much of the soil diversity in Amazonia has originated from the considerable differences in geology and geomorphology history that occur across the Basin. In particular, the Andean orogeny generated tectonic load and sediment flux into lowland Amazonia, deeply transforming a previously craton dominated land into the diverse edaphic mosaic of present day (Hoorn et al., 2010). Interestingly, much early work on this subject was not by soil scientists or geomorphologists, but rather by limnologists interested in the causes of observed variations in the elemental composition of river waters within the Basin. Based on such observations, Fittkau (1971) divided the Amazon Basin into four regions, as shown in Fig. 1a. He considered the characteristically low levels of chemical elements (especially calcium) found in the waters of the core area of Central Amazonia (Sub-region IV in Fig. 1a) to reflect the already low soil fertility of this region (Aubert and Tavernier, 1972), this being associated with the lack of geological activity in recent times. In addition, it was argued that the sediments deposited in this area would also have had a very low nutrient content, such as for the sands derived from the ancient Guyana shield, which is at least about 1700 million years old (Fittkau et al., 1975). High topographic stability combined with continuous hot and wet weather has also already resulted in a deep weathering and leaching of parent material with lack of erosion over the generally flat topography eliminating bedrock as a source of nutrients for this part of Amazonia.

Figure $1 b$ shows variation in maximum geological age for the different provinces in the Amazon Basin. For the area encompassing Fittkau's region IV specifically, it is possible to differentiate large differences in substrate age with the region involving the Madeira, Juruá, Purús and Tapajos Basins being considerably younger than the remaining of Fittkau's region IV (east of Manaus) which represents the much older Barreiras and Alter do Chão Formations. There should be a difference in geological age of at least 100 million years between these areas, with the Madeira, Juruá, Purús and Tapajos Basin formerly being under influence of the Pebas and Acre marine/fluvial systems between 23 and 7 million years ago (Hoorn et al., 2010). The soils

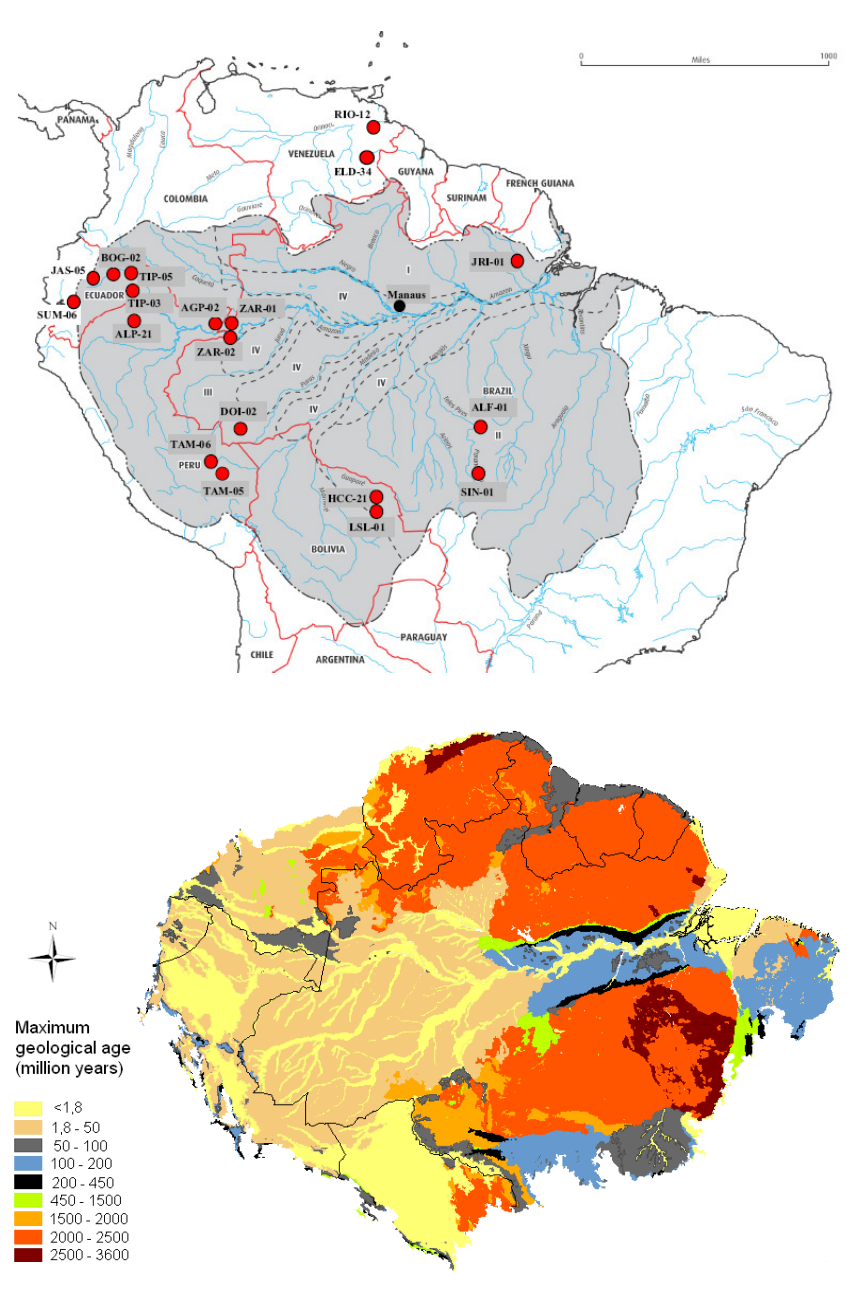

Fig. 1. (a) Division of the Amazon Basin fertility regions according to Fittkau (1971). (I) Guyana shield; (II) Brazilian shield; (III) Western peripheral area and (IV) Central Amazonia. Study sites depicted in this map relate to soil profiles used as examples in this paper. (b) Maximum geological age for Amazonia (from Schobbenhaus and Bellizzia, 2001).

of Fittkau's Central Amazonian sub-region IV (east of Manaus) are mainly derived from rocks and sediments from the middle Tertiary with a high probability of belonging to the end of the Cretaceous and thus likely to have experienced more or less continuous weathering for more than 20 million years (Irion, 1978). Included in this sub-region, the socalled Barreiras formation was originated from CretaceousTertiary sediments, derived from the erosion of the Guyana and Brazilian shields (Herrera et al., 1978). This formation has been exposed for at least 100 million years (Fig. 1b) and has been subjected to several cycles of erosion, deposition and sedimentation. Such differences in geological history have resulted in the well documented contrasting levels of soil fertility and pedogenetic development between these regions (RADAMBRASIL, 1978). 
Fittkau (1971) also found the natural waters of his peripheral sub-regions (Northern, Western and Peripheral Amazonia in Fig. 1a) to be significantly richer in chemical elements than the central Amazon Basin with the waters of Western Peripheral Amazonia being considerably enriched. Not surprisingly, these are also the areas in the Amazon Basin where relatively fertile soils occur: This particularly being the case close to the Andes where topography plays an important role in the maintenance of soil fertility through erosion of the soil surface and exposition of the underlying parent material (Jordan and Herrera, 1981).

Encompassing Fittkau's regions I and II respectively, the ancient, pre-Cambrian Guyana and Brazilian shields, with their series of igneous and metamorphic rocks, are placed to the north and south of the lower Amazon River. These are the oldest surfaces exposed in South America, with their maximum geological age ranging from 1500 to 3600 million years (Fig. 1b). Despite being very old, most soils have been formed in situ by the weathering of underlying crystalline rocks (i.e. not derived from reworked sediments), which explains the occasional occurrence of unexpectedly high fertility soils in these two regions.

Between these shields and the Amazon River (Fittkau's region IV) occur strips of Palaeozoic sediments in which Devonian shales are represented to an appreciable extent (Irion, 1978; Hoorn et al., 2010). By contrast, western Amazonian soils (Fittkau's region III) mostly consist of pre-Andine sediments from the Cretaceous-Tertiary period uplifted in the Pliocene. Despite some regional variation in maximum age (Fig. 1b), most of this formation probably commenced between 1 and 2 million years ago. For instance, at the neighbourhood of Acre state, Brazil, a number of fresh water and marine sediments occur as a result of the Andean orogeny and fluctuations of the sea level during warmer climates (Irion, 1978; Kronberg et al., 1989, 1998; Hoorn et al., 2010). Also, the western Amazon region includes large areas where shallow soils on hillslopes dominate. Thus active contributions of weathering of parent material to soil fertility can be expected (Irion, 1978).

Floodplain soils of western Amazonia are also much more recent. Formed in the Pleistocene and Late Holocene, these soils are not much older than 5000 years (Irion, 1978). Although Fittkau's region III has usually been considered fertile (Sanchez and Buol, 1975), soils within this region often contain extremely high exchangeable aluminium levels (Lips and Duivenvoorden, 1996); a consequence of the ongoing weathering of high activity aluminium bearing minerals such as hydroxyl-interlayered vermiculite (Marques et al., 2002; Lima et al., 2006).

As noted already, differences in geomorphology and soil fertility across Amazonia are reflected in the dissolved elemental compositions of the waters in the rivers draining each region (see also Herrera et al., 1978; Irion, 1984; Medina and Cuevas, 1989; Furch and Klinge, 1989; Gaillardet et al., 1997). In that respect, Amazon tributaries which originate in the Andean region are often termed "white-water rivers". These rivers are in fact brown in colour due to suspended particles eroded from mountain slopes, but what is important is that they have higher levels of all nutrients compared to other Amazonian rivers, notably $\mathrm{Ca}, \mathrm{P}$ and $\mathrm{Mg}$ (Furch and Klinge, 1989) - although concentrations are still below the average when compared to rivers draining the temperate and boreal regions (Herrera et al., 1978). Nutrient rich floodplain soils result from sediment deposition from such white-water rivers (the Várzea); and such soils have been considered the flooded counterpart of the fertile and well-drained terra firme soils of western Amazonia (Furch and Klinge, 1989). Examples of white-water rivers include the Solimões, Juruá and Madeira, all of whom have their headwaters draining the Andean Cordillera with complex and varied lithologies (Gaillardet et al., 1997). In the Solimões Basin the core of the Cordillera consists of a pre-Cambrian basement formed either by sediments, igneous or metamorphic rocks. Evaporites, dark shales, fractured carbonates and Mesozoic red beds are the main rocks overlying the basement. Further downstream, Tertiary fluvio-lacustrine sediments (Içá formation) dominate the lowland portions of the Solimões River (Gaillardet et al., 1997; Hoorn et al., 2010). In the Andean part of the Madeira River, the main rocks are Palaeozoic sediments associated with shales and rare Cambrian evaporites. The Juruá and the lowland portions of Madeira and Solimões Rivers drain Tertiary fluvio-lacustrine deposits (Gaillardet et al., 1997).

By contrast, waters that drain the pre-Cambrian Guiana and Brazilian shields are generally known as "black-water" rivers, with the dark colour of their waters due to high concentrations of dissolved humic and fulvic acids in various stages of polymerization (Herrera et al., 1978; Gaillardet et al., 1997). But some tributaries that originate in the eastern and central areas of Amazonia, usually draining Ferralsols, are often "clear", with transparent, crystalline waters (Herrera et al., 1978). Neither black nor clear water rivers carry appreciable suspended soils particle loads. They are also characterised by very low nutrient concentrations - a consequence of the low nutrient content of the substrates from which these rivers drain (Herrera et al., 1978).

The Rio Negro is probably the best example of an Amazonian black water river. The very low nutrient concentrations of the soils that drain into it have arisen as a result of several cycles of weathering, erosion, and sedimentation. All nutrients are found in very small amounts with [Ca] being notably low (Furch and Klinge, 1989).

This paper provides an up to date review of the most important soil types of the Amazon Basin, adopting the World Reference Base (WRB) approach for soil classification (IUSS Working Group WRB, 2006). Distribution maps of the main soil types occurring under forest vegetation and its respective cover area are also introduced using the World Soil Information Database (ISRIC, 1995). We contextualize the soils into an evolutionary framework, doing so by 
Table 1. Soil area beneath forest vegetation in Amazonia.

\begin{tabular}{lcc}
\hline Reference Soil Group & Area $\left(\times 10^{12} \mathrm{~m}^{2}\right)$ & Cover fraction \\
\hline Ferralsols & 2.350 & 0.316 \\
Acrisols & 2.154 & 0.289 \\
Plinthosols & 0.648 & 0.087 \\
Gleysols & 0.615 & 0.083 \\
Cambisols & 0.418 & 0.056 \\
Leptosols & 0.405 & 0.054 \\
Arenosols & 0.200 & 0.027 \\
Fluvisols & 0.187 & 0.025 \\
Regosols & 0.144 & 0.019 \\
Lixisols & 0.142 & 0.019 \\
Podzols & 0.141 & 0.019 \\
Alisols & 0.020 & 0.003 \\
Histosols & 0.016 & 0.002 \\
Nitisols & 0.002 & $<0.001$ \\
\hline Total & 7.444 & 1 \\
\hline
\end{tabular}

proposing a scheme of soil development based on a chemical weathering index. As well as drawing on previous work of others, original data is also presented to help demonstrate the diversity of Amazonian soils, both within and between the various WRB soil groups.

\section{Material and methods}

\subsection{Study sites}

The soils of a total of 71 primary forest plots are used in this study, including forests in Brazil, Bolivia, Colombia, Peru, Ecuador and Venezuela. A subset of 18 soil profiles is used to exemplify soil characteristics among and within each WRB group. The geographic distribution of these sites is shown in Fig. 1a. Details for each site are also given in Table 1 of Quesada et al. (2010) along with a map showing the geographic distribution of each site and their soil classification up to RSG level (Fig. 1 of Quesada et al., 2010).

\subsection{Soil sampling and laboratory methods}

Detailed descriptions of soil sampling and laboratory methods are given in Quesada et al. (2010) but are also briefly summarised here. Exchangeable cations were determined by the silver thiourea method (Pleysier and Juo, 1980), soil carbon was determined in an automated elemental analyser as described by Pella (1990) and Nelson and Sommers (1996). Particle size analysis was undertaken using the Boyoucos method (Gee and Bauder, 1986).

For the purposes of soil classification, cation exchange capacity (CEC) and exchangeable bases were also measured by ammonium acetate $\mathrm{pH} 7\left(\mathrm{NH}_{4} \mathrm{Ac} \mathrm{pH} 7\right.$, Van Reeuwijk, 2002) on all pit samples. According to the requirements of the WRB soil classification system, CEC values were adjusted for organic matter content and expressed on clay basis. Further, although exchangeable $\mathrm{Al}$ had been routinely analysed using the silver thiourea method (Quesada et al., 2010) for selected Brazilian samples it was also determined by the more common $1 \mathrm{M} \mathrm{KCl}$ extraction method (Van Reeuwijk, 2002). Thus, all pit samples had been analysed using the AgTU method, with a subset of these samples analysed by both methods.

With the purpose of using exchangeable $\mathrm{Al}$ as an aid for soil classification using the WRB, $[\mathrm{Al}]$ values obtained from $\mathrm{Ag}$-TU extracts were then adjusted to $1 \mathrm{M} \mathrm{KCl}$ levels using an equation derived by the means of a non parametric regression. This showed the two methods to correlate well (Fig. 2a), but with $\mathrm{Al}$ extracted by $1 \mathrm{M} \mathrm{KCl}$ tending to be slightly less at low concentrations and somewhat greater at high concentrations.

Exchangeable bases extracted by $\mathrm{NH}_{4} \mathrm{Ac} \mathrm{pH} 7$ yielded comparable results to extractions made by the Ag-TU method (Fig. 2b) with the exception of some samples with very low concentrations which were more strongly extracted by Ag-TU. In agreement with the similarities in extraction levels of exchangeable bases and aluminium by the two methods (Fig. 2), soil ECEC extracted by $\mathrm{NH}_{4} \mathrm{Ac} \mathrm{pH} 7$ and Ag-TU were very similar (Fig. 3a). Nevertheless, CEC values determined by ammonium acetate $\mathrm{pH} 7$ almost inevitably yielded substantially higher values than did ECEC calculated from the Ag-TU extractions (Fig. 3a). Again differences in extraction levels were higher at lower cation concentrations and declined with increasing concentrations. Such differences in extraction power relate to the artificial charges created on the surface of variable charge colloids at higher soil pH (Uehara and Gilman, 1981) with the differences in extraction power of CEC and ECEC resulting in very different apparent base saturation levels (Fig. 3b). Indeed, the calculation of base saturation by $\mathrm{NH}_{4} \mathrm{Ac} \mathrm{pH} 7$ for the soils in this study almost always resulted in values less than 0.5 and in the placement of soils in the dystric category despite soils sometimes having high levels of exchangeable bases and base saturation in Ag-TU.

To investigate the weathering levels of soils within the dataset, the weathering index Total Reserve Bases $\left(\Sigma_{\mathrm{RB}}\right)$ was calculated. This index is based on total cation concentration in the soil and is considered to give a chemical estimation of weatherable minerals (Delvaux et al., 1989). Soil samples $(0.0-0.3 \mathrm{~m})$ were extracted for total elemental concentrations $(\mathrm{Ca}, \mathrm{Mg}, \mathrm{K}$ and $\mathrm{Na}$ ) by strong acid digestion using concentrated sulphuric acid followed by $\mathrm{H}_{2} \mathrm{O}_{2}$, with $\Sigma_{\mathrm{RB}}$ equal to $[\mathrm{Ca}]_{\mathrm{T}}+[\mathrm{Mg}]_{\mathrm{T}}+[\mathrm{K}]_{\mathrm{T}}+[\mathrm{Na}]_{\mathrm{T}}$, where $[\mathrm{X}]_{\mathrm{T}}$ represents the total concentration of each element in mmol $_{\mathrm{c}} \mathrm{kg}^{-1}$ soil.

\subsection{Representation of soil profiles}

To illustrate representative vertical profiles of exchangeable cation concentrations, $[\mathrm{C}]$ and soil particle size distribution, 


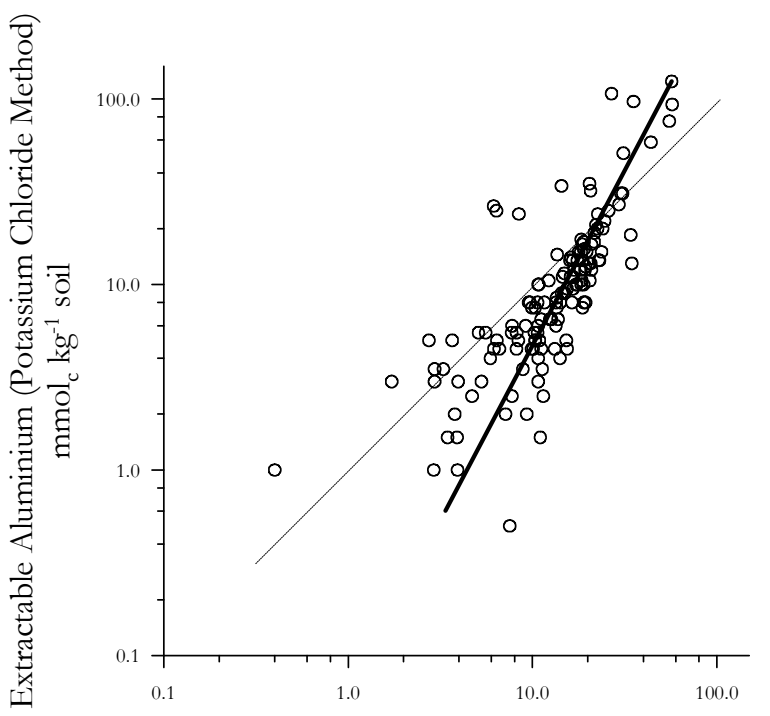

Exrtractable Aluminium (Silver Thiourea Method) $\mathrm{mmol}_{\mathrm{c}} \mathrm{kg}^{-1}$ soil

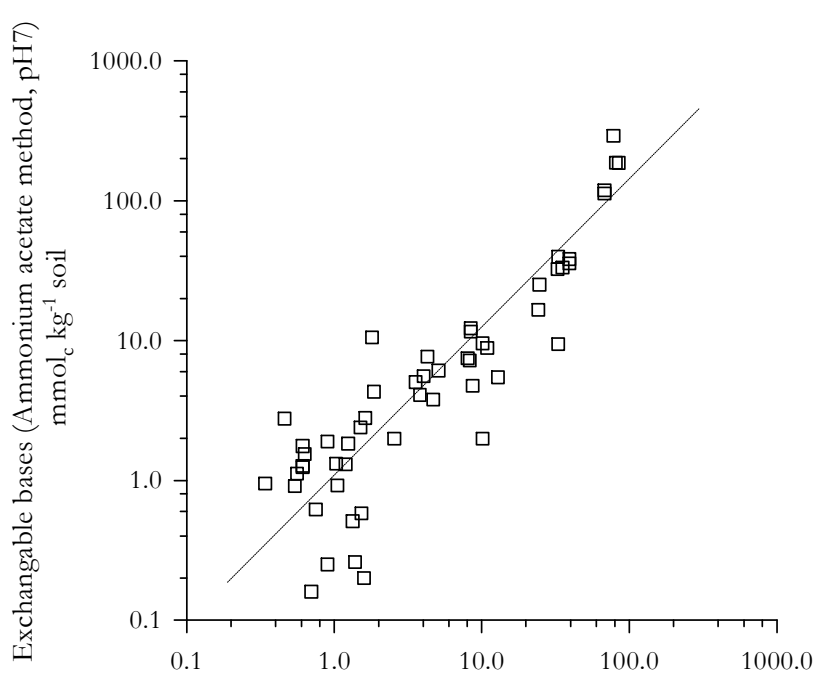

Exchangable Bases (Silver thiourea method) $\mathrm{mmol}_{\mathrm{c}} \mathrm{kg}^{-1}$ soil

Fig. 2. Cation extraction methods compared: (a) relationship between $\mathrm{KCl}$ versus AgTU extractable aluminium. (b) Exchangeable bases extracted by $\mathrm{NH}_{4} \mathrm{Ac}$ at $\mathrm{pH} 7$ as a function of $\mathrm{AgTU}$ exchangeable bases.

we used the equal area quadratic smoothing spline approach of Bishop et al. (1999) using a value for the smoothing parameter, $\lambda$, of 0.01 with all profile depths, $z$, standardised prior to the fitting of the spline according to $z *=z / z_{\max }$ where $z *$ is the standardised value and $z_{\max }$ is the maximum depth sampled. As detailed in Quesada et al. (2010) soils were typically sampled over a series of depths viz 0.00-0.05 m, 0.05-0.10 m, 0.10-0.20 m, 0.20-0.30 m, 0.30$0.50 \mathrm{~m}, 0.50-1.00 \mathrm{~m}, 1.00-1.50 \mathrm{~m}$ and $1.50-2.00 \mathrm{~m}$. Where physical constraints prevented sampling to $2 \mathrm{~m}$ depth, $z_{\max }$ was taken as the depth at which sampling stopped and the
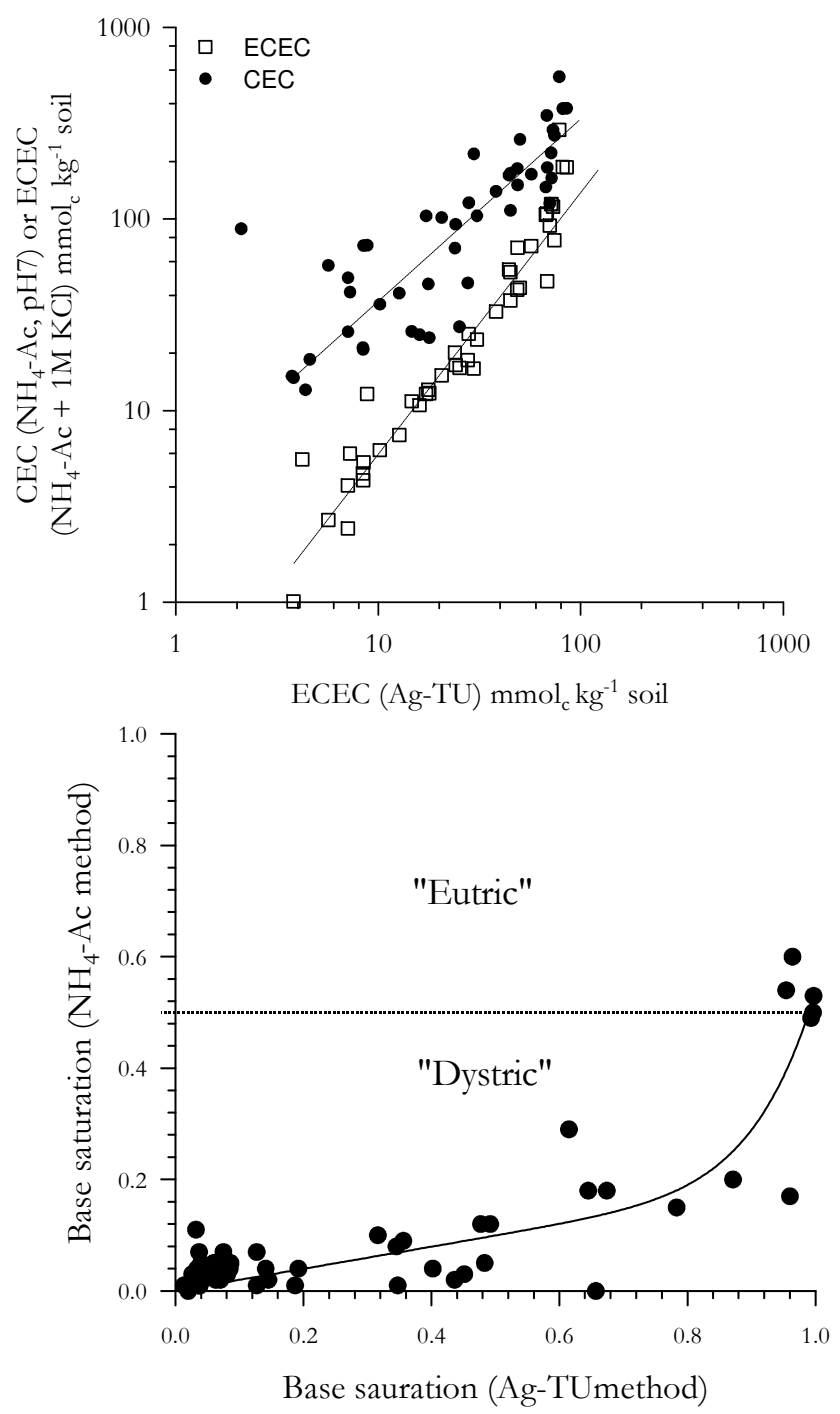

Fig. 3. Cation extraction methods compared. (a) Cation exchange capacity (CEC) as determined by $\mathrm{NH}_{4} \mathrm{Ac}(\mathrm{pH} 7)$ and effective CEC (ECEC) as estimated by summing extractable bases $\left(\mathrm{NH}_{4} \mathrm{Ac}\right)$ and extractable aluminium $(\mathrm{KCl})$ together, both plotted as a function AgTU extracted ECEC (sum of bases plus aluminium) (b) Base saturation calculated using $\mathrm{NH}_{4} \mathrm{Ac}(\mathrm{pH} 7)$ as a function of base saturation estimated with AgTU.

number of horizons in the fitting program adjusted accordingly. Note that in all graphs presented here, cation values presented are for the Ag-TU extractions only.

\subsection{Preparation of soil distribution maps}

The Soil and Terrain database for Latin America and the Caribbean (SOTERLAC), version 2.0, at a scale of 1:5000000 (Dijkshoorn et al., 2005) was used as the basis for defining soils classes and their spatial distribution. Non-forested areas were excluded from the analysis using a 


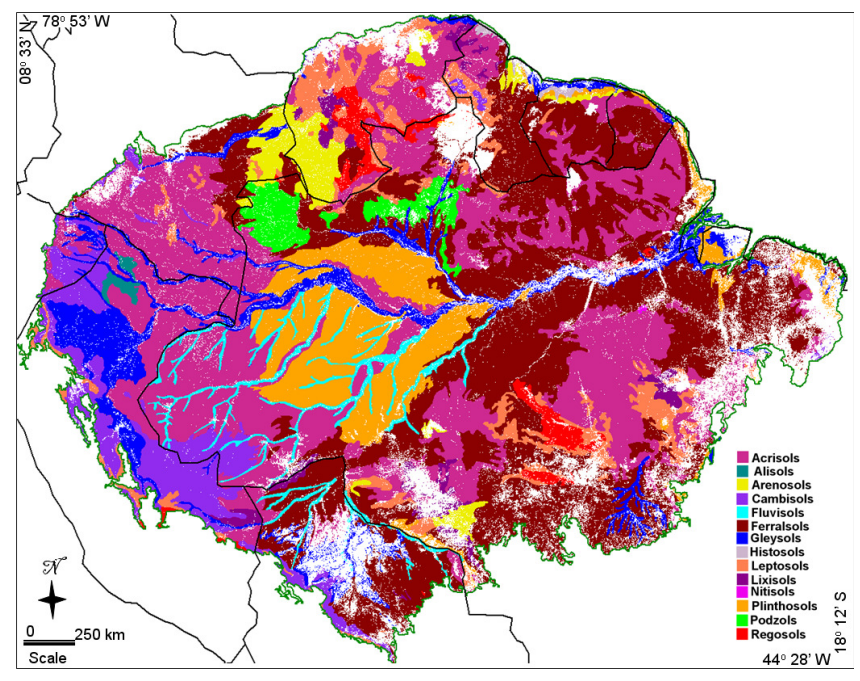

Fig. 4. Basin wide distributions of soils under forest vegetation. Map based on the SOTERLAC-ISRIC soil database (version 2.0, 1:5 million scale) and the vegetation database of Saatchi et al. (2008) for South America.

vegetation map derived from optical and microwave remote sensing data over the Amazon basin, at $1 \mathrm{~km}$ spatial resolution, capable of discriminating 16 land cover types and with an overall accuracy of above 0.85 (Saatchi et al., 2008). The following land cover classes were aggregated and considered as "forest": closed terra firme forest, open/degraded terra firme forest, bamboo/mixed semi-deciduous forest, liana dominated/open forest, transitional/deciduous forest, submontane forest, montane forest, closed woodland, closed swamp forest, open swamp forest and mixed vegetation swamp.

The sub-division of the soil classes provided in the dataset from SOTERLAC were aggregated into the following main categories to encompass all the variability per WRB Soil Reference Group (RSG): Acrisols, Alisols, Arenosols, Cambisols, Fluvisols, Ferralsols, Gleysols, Histosols, Leptosols, Lixisols, Nitisols, Plinthosols, Podzols and Regosols. Other soils were not mapped due to their limited coverage in Amazonia; these being Andosols, Solonchak, Solonetz, Phaeozems and Luvisols. A Geographic Information System (GIS) was used to compile and carry out map algebra with the reclassified soil and vegetation maps combined using Boolean operators in order to generate a final result of soil types on forested vegetation formations.

\section{Results and discussion}

\subsection{Describing Amazonian forest soils: distribution and diversity}

The distribution and coverage across each Reference Soil Group (RSG) are shown in Fig. 4. Individual maps for the principal RSG are also shown in the Supplementary Information. These show that the geographic distributions of forest soils vary widely across the Amazon Basin and are usually associated with large scale geomorphologic features. For example, Acrisols and Ferralsols occur mainly on the Brazilian and Guyana shields and in the sedimentary zone along the central and eastern portions of the Amazon River. Although Ferralsols are absent in western and south-western areas of the Basin, Acrisols do occur in this region, but are apparently limited to Tertiary fluvio-lacustrine deposits and other sedimentary formations near the Andes. Other soils occur almost exclusively in the vicinity of the Brazilian and Guyana shields such as Arenosols, Lixisols, Nitisols, Histosols and Podzols, with the latter occurring in areas of the Rio Negro basin as well. Plinthosols also occur in small patches along the Brazilian and Guyana shields but are most common in sedimentary areas near the Juruá, Purus and Madeira rivers (i.e. Içá formation).

Regosols and Leptosols occur along both Shields but are most common in the proximity to the Andean foothills mostly outside of the Amazonian border. Floodplains and areas along the major rivers account for most of the Fluvisols and Gleysols, such as the catchments of the upper Amazon tributaries and along the Amazon itself. Large Gleysol patches also occur in the Araguaia catchments in Brazil and in north Colombia, also spreading along the Andean border in sedimentary zones in the Peruvian Amazon. Some other soils are mapped as occurring almost exclusively in the Andean foothills and adjacent sedimentary zone such as Cambisols and Alisols. Indeed, the proportions of soils occupying the eutric lower classification levels (Quesada et al., 2010) are much greater in this zone. The coverage of each soil group is summarized in Table 1. Ferralsols and Acrisols alone account for 0.61 of Amazonian forest soils, with Plinthosols, Gleysols, Cambisols and Leptosols accounting for most of the remaining portion $(0.09,0.08$, 0.06 and 0.05 respectively). All the remaining soils altogether cover less than 0.12 of the area. We note that the estimation of soil coverage shown is based only on soils underneath forest, and that the area mapped is defined for a new definition of the Amazon border (Soares-Filho et al., 2006).

Accounting for the diversity of Amazonian soils, Table 1 in Quesada et al. (2010) lists geographic coordinates, country of location and the identified soil type for the 71 sites sampled as part of that study. This shows that of the 32 RSG in the WRB classification scheme, 14 Reference Soil Groups were identified, viz. one Leptosol, five Gleysols, one Fluvisol, 13 Cambisols, one Andosol, one Nitisol, 10 Plinthosols, two Umbrisols, 10 Alisols, one Lixisol, seven Acrisols, 13 Ferralsols, two Arenosols and four Podzols. A large variation within RSG was also found, with three lower level differentiations for Alisols, two for Acrisols, seven for Cambisols, five for Ferralsols, two for Plinthosols, two for Podzols and two for Gleysols. Geographical locations of the soils (Fig. 1 of Quesada et al., 2010) suggest our sampling 


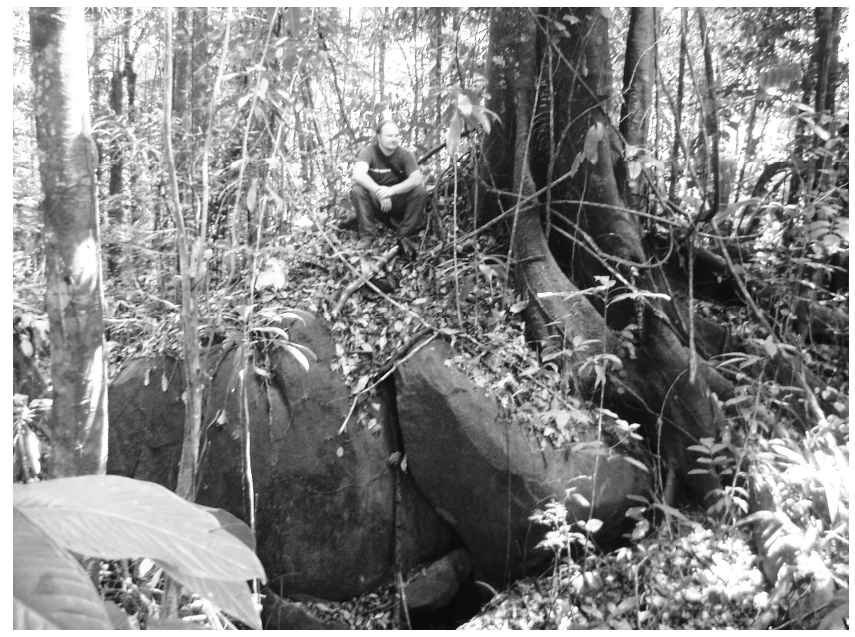

Fig. 5. Forest vegetation above a Leptosol in Venezuela (ELD-34).

to have given a reasonable representation of the soils of the Amazon basin in six different countries.

With a view to demonstrating the diversity of soils in Amazonia, each of the 14 different major Reference Soil Groups found in our study are now considered. Representative soil profile data is given for each soil group, with additional profiles given for soils showing significant variation within their RSG. As in Driessen et al. (2001), soils are organized according to the major factors conditioning their morphological, chemical and physical properties.

\subsection{Soils conditioned by limited age}

\subsubsection{Leptosols}

Leptosols (some Entisols, Orthents and other lithic subgroups in US Soil Taxonomy) are shallow soils over continuous rock or soils that are extremely gravelly and/or stony. Although being azonal, Leptosols tend to be found on rock outcrops and mountainous regions (Driessen et al., 2001). Here they usually occur on rocks that are resistant to weathering, where erosion has kept pace with soil formation, or where the soil surface has been removed (Buol et al., 2003). They are characterized by various kinds of continuous rocks or unconsolidated material with less than 0.2 of fine earth by volume. Within the Amazon Basin they often support short forest or savannas as in the Inselberg complexes in the frontier zone of Guyana, Brazil, Venezuela and Colombia, as well as in the Andean fringe (Reatto et al., 1998; Cotler and Maass, 1999; Sombroek, 2000).

Nevertheless, Leptosols do occur under forest and one example can be seen in Fig. 5, here illustrating one of the highest forest biomass in our dataset with many large trees over almost bare rock. Figure 6 show the profiles of $\mathrm{Ca}, \mathrm{Mg}$, $\mathrm{K}, \mathrm{Na}, \mathrm{Al}$ and soil carbon for this Hyperskeletic Leptosol (Orthodystric) in Venezuela (ELD-34). Consistent with the

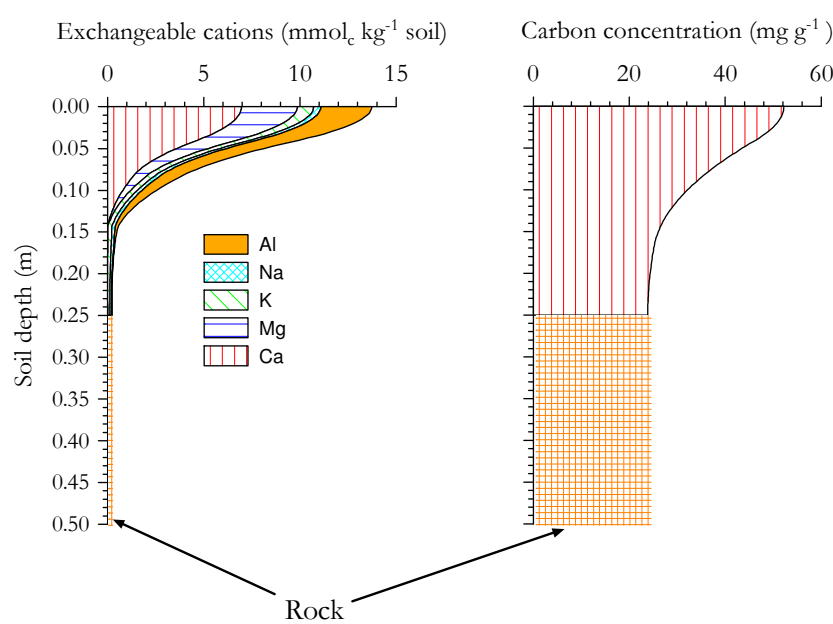

Fig. 6. Profiles of exchangeable cations and soil carbon for a Hyperskeletic Leptosol (Orthodystric) in Venezuela (ELD-34).

suffix "Orthodystric", exchangeable cations concentrations were moderately low, reflecting both parent material fertility and the small degree of development of this soil. Nutrients were found only in the top soil, where organic materials accumulate. The fine earth fraction was very coarse $(<0.20$ as fine earth fraction), mostly due to mineral fragments which had not been broken down to a fine degree, thus granting this soil with the qualifier "Hyperskeletic". The soil depth was very variable, but usually not exceeding $0.25 \mathrm{~m}$. In terms of vertical structure, the soil had a well developed litter layer above a thin soil horizon over rock. The diabase rock from which this soil originates is resistant to weathering and bare rock outcrops accounted for most of the ground surface, with the soil mostly appearing in concave portions of the terrain or in cracks among the rocks. The relatively high carbon content of this soil seems to reflect the accumulation of litter in the surface, as there is little opportunity for carbon to move down in the soil, being thus ultimately conditioned by the soil depth.

With the purpose of facilitating an understanding of WRB qualifiers for readers not familiar with this soil classification, Table 2 lists a glossary with the meaning for the most common suffix and prefix used through the text. Complete descriptions of each qualifier can be found at IUSS working group WRB (2006).

\subsubsection{Cambisols}

The Cambisol group (Inceptsols in US Soil Taxonomy) consists of soils with incipient formation. The initial stages of transformation in the soil material are evident, with developing soil structure below the surface horizon and discolorations (Driessen et al., 2001). Cambisols tend to evolve from a variety of medium and fine textured parent materials. They are also characterized by profiles of only slight 
Table 2. Glossary of WRB qualifiers used through the text. For complete description of soil classification terms see IUSS Working Group WRB (2006), report 103.

\begin{tabular}{|c|c|}
\hline Qualifier & Description \\
\hline Acric & $\begin{array}{l}\text { Soils having argic horizon, low activity clay and low base saturation. Occurs as prefix qualifier in soils where other diagnostic } \\
\text { properties have prevalence (i.e. Acric Ferralsol) }\end{array}$ \\
\hline Albic & $\begin{array}{l}\text { Light-coloured subsurface horizon in which free iron oxides and clay have being removed or segregated, revealing the true } \\
\text { colour of remaining sand and silt particles }\end{array}$ \\
\hline Alumic & Having $\mathrm{Al}$ saturation $\geq 0.5$ in some layer between $0.5-1 \mathrm{~m}$ from surface \\
\hline Andic & Properties resulting from the moderate weathering of pyroclastic material \\
\hline Arenic & Having a texture of loamy fine sand or coarser in a layer $\geq 0.3 \mathrm{~m}$ within $1 \mathrm{~m}$ from surface \\
\hline Argic & Subsurface horizon with distinct higher clay content than the overlying horizon \\
\hline Cambic & Subsurface horizon showing evidence of alteration in relation to least weathered underlying horizons. \\
\hline Clayic & Having a texture of clay in a layer $\geq 0.3 \mathrm{~m}$ within $1 \mathrm{~m}$ from surface \\
\hline Cutanic & Having clay coatings in some part of an argic horizon \\
\hline Endogleyic & Having reducing conditions between 0.5 and $1 \mathrm{~m}$ from surface AND gley colour patterns in 0.25 or more of the soil volume \\
\hline Endostagnic & Having stagnic colour patterns and reducing conditions \\
\hline Ferric & Having an horizon with segregation of $\mathrm{Fe}$ or $\mathrm{Fe}$ and $\mathrm{Mn}$ \\
\hline Ferralic & $\begin{array}{l}\text { Subsurface horizon resulting from long and intense weathering in which the clay fraction is dominated by low-activity clays } \\
\text { and the silt and sand fractions by highly resistant minerals, such as oxides of } \mathrm{Fe}, \mathrm{Al}, \mathrm{Mn}\end{array}$ \\
\hline Geric & Soils with very low ECEC \\
\hline Gibbsic & Having 0.25 or more gibbsite in the fine earth fraction \\
\hline Haplic & Indicates soils not associated to any specific or intergrade qualifier. Used only when no other prefix applies \\
\hline Hyperalic & In Alisols only: soils having silt/clay ratio $<0.06$ and $\mathrm{Al}$ saturation $\geq 0.5$ \\
\hline Hyperskeletic & Having less than 0.2 fine earth fraction by volume \\
\hline Hyperdystric & $\begin{array}{l}\text { Base saturation } \leq 0.5 \text { throughout between } 0.2 \text { and } 1 \mathrm{~m} \text { from surface AND }<0.2 \text { base saturation in some layer within } 1 \mathrm{~m} \text { from } \\
\text { surface }\end{array}$ \\
\hline Hypereutric & $\begin{array}{l}\text { Base saturation } \geq 0.5 \text { throughout between } 0.2 \text { and } 1 \mathrm{~m} \text { from surface AND } \geq 0.8 \text { base saturation in some layer within } 1 \mathrm{~m} \text { from } \\
\text { surface }\end{array}$ \\
\hline Melanic & $\begin{array}{l}\text { Thick, black surface horizon, which is associated with short-range-order minerals (commonly allophone) or with organo- } \\
\text { aluminium complexes, typically originated from pyroclastic material. }\end{array}$ \\
\hline Mollic & Well structured, dark coloured surface horizon, with high base saturation and moderate to high organic matter content \\
\hline Nitic & Distinct clay-rich subsurface horizon with well developed polyhedric or nutty structure with many shiny ped faces \\
\hline Orthodystric & Base saturation $\leq 0.5$ throughout between 0.2 and $1 \mathrm{~m}$ from surface \\
\hline Orthoeutric & Base saturation $\geq 0.5$ throughout between 0.2 and $1 \mathrm{~m}$ from surface \\
\hline Ortsteinc & Having a cemented spodic horizon \\
\hline Oxyaquic & Saturated with $\mathrm{O}_{2}$ rich water for more than 20 days AND no gleyic or stagnic colour pattern \\
\hline Plinthic & $\begin{array}{l}\text { Subsurface horizon that consists of an Fe-rich humus-poor mixture of kaolinitic clay with quartz and other constituents, and } \\
\text { which changes irreversibly to a layer with hard nodules, a hardpan or irregular aggregates on exposure to repeated wetting and } \\
\text { drying with free access of oxygen }\end{array}$ \\
\hline Rhodic & Very red soils \\
\hline Silandic & In Andosols only: having one or more layer with andic properties $\mathrm{AND} \mathrm{Si}_{\mathrm{ox}} \geq 0.06 \mathrm{OR}$ an $\mathrm{Al}_{\mathrm{py}}$ to $\mathrm{Al}_{\mathrm{Ox}}$ ratio of less than 0.5 \\
\hline Siltic & Having texture of silt, silt loam, silt clay loam or silt clay in a layer $\geq 0.3 \mathrm{~m}$ within 0.5 and $1 \mathrm{~m}$ from surface \\
\hline Spodic & Subsurface horizon that contains illuvial amorphous substances composed by organic matter and $\mathrm{Al}$ or Fe \\
\hline Umbric & Thick, dark-coloured, base-depleted surface horizon rich in organic matter \\
\hline Vetic & Having ECEC of less than $60 \mathrm{mmol}_{\mathrm{c}} \mathrm{kg}^{-1}$ clay in some layer within $1 \mathrm{~m}$ from surface \\
\hline Vitric & $\begin{array}{l}\text { Properties related to soil layers rich in volcanic glass and other primary minerals derived from volcanic ejecta, which contain a } \\
\text { limited amount of short-range-order minerals }\end{array}$ \\
\hline Xanthic & Very yellow soils \\
\hline
\end{tabular}


or moderate weathering, and by the absence of appreciable quantities of clay illuviation, organic matter accumulation or readily extractable aluminium and iron compounds (IUSS Working Group WRB, 2006). Most Cambisols are soils with some horizon differentiation and are in a transitional stage of development; actively developing from a young soil to a more mature form which will have an argic, spodic or ferralic B horizon (Buol et al., 2003). The Cambisol group keys out late in the WRB taxonomy hierarchy which implies that this group may include some soils that just missed out one or more requirements for other reference groups (IUSS Working Group WRB, 2006). High quantities of weatherable minerals and the absence of any signs of advanced pedogenesis is further evidence of the early stages of the soil formation characteristic of cambisols (Sanchez, 1976; Buol et al., 2003). There is however, often evidence of initial weathering and transformation of primary minerals (Sanchez, 1976; Buol et al., 2003). The cambisols of tropical regions generally occur in recent geomorphic surfaces that may be erosional or aggradational (Driessen et al., 2001). Given the high weathering intensity of the tropics, young alluvial deposits and fresh rocks exposed at shallow depths may evolve to cambisols in a relatively short time (Buol et al., 2003). Most cambisols in this study were found close to the Andes on erosional surfaces in western Amazonia, but this soil type has also been reported to occur along the Solimões river floodplain (Moreira et al., 2009).

Figure 7 shows two Cambisol profiles of contrasting fertility: A Haplic Cambisol (Alumic, Hyperdystric, Clayic) located at Tambopata, south Peru (TAM-05, Fig. 7a) and a Haplic Cambisol (Orthoeutric) located in Ecuador (BOG-02, Fig. 7b). For the Peruvian soil, exchangeable bases were very low, declining strongly with depth, but with exchangeable aluminium concentrations high, and increasing slightly with depth. Soil carbon was higher in the soil surface due to organic matter inputs from the forest litterfall, whilst as for most profiles examined as part of this study subsurface carbon declines slowly with depth. Clay content was high, also increasing slightly with depth, but in this case such an increase in the control section does not fulfill the requirements for argic horizon such as is the case for Alisols, Acrisols and Lixisols (Sect. 3.3.3 to 3.3.5). The elevated aluminium proportion of this soil and its high clay content confers the suffix descriptors "Alumic" and "Clayic". This soil had a maximum depth of $1.7 \mathrm{~m}$ below which saprolite was present. The vertical distributions of clay and [Al] suggest that transformations towards another soil type are currently taking place, with this soil most likely evolving to an Alisol. Suggestive routes for soil development are discussed further in Sect. 3.7.

By contrast the exchangeable bases for BOG-02 were among the highest found in Amazonia (Fig. 7b) with very low extractable aluminium content, and cation concentrations varying little with depth, this granting this soil the denomination "Orthoeutric". Carbon profiles showed a sharp decline in depth. Soil texture was sandy clay loam to clay
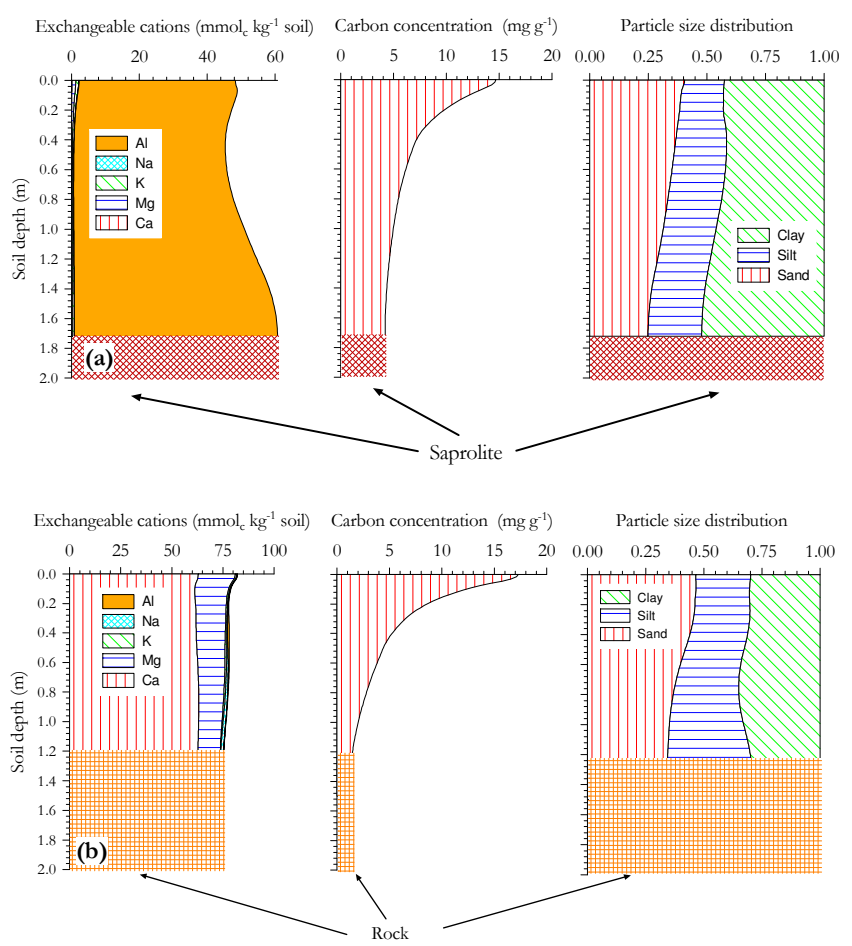

Fig. 7. Profiles of exchangeable cations, soil carbon and texture for (a) a Haplic Cambisol (Alumic, Hyperdystric, Clayic) in south Peru (TAM-05) and (b) a Haplic Cambisol (Orthoeutric) in Ecuador (BOG-02).

loam, this being considered typical for this type of soil. Soil depth was shallow, reaching saprolite at $0.8 \mathrm{~m}$ and rock at $1.1 \mathrm{~m}$. This soil was strongly conditioned by its steep topography being constantly renovated by erosion.

As also noted by Sombroek (1984), the above comparison illustrates the importance of appreciating that Cambisols are highly variable in terms of their fertility. This variation occurs because their close proximity to parent material makes them strongly dependent on quality of the weathering substrate. Also, varying degrees of weathering and mineral transformation are observed, adding to the variability found (Buol et al., 2003). Another source of variability in soil fertility may rise from the inclusion in this classification group of soils that just failed criteria for other groups (Wilding et al., 1983; IUSS Working Group WRB, 2006). Although this did not seem to be a significant factor for this study.

\subsection{Soils conditioned by a wet tropical climate}

\subsubsection{Plinthosols}

Plinthosols (Plinthic Great Groups in US Soil Taxonomy) are soils which have as their principal characteristic the elevated concentration of plinthite, an iron rich, humus poor mixture of kaolinite clay and quartz which changes irreversibly to hardpans on exposure to repeated wet and drying 
cycles (Sombroek, 1984; IUSS Working Group WRB, 2006). Plinthite most commonly evolves from the weathering material of basic rocks as opposed to acidic ones. As formation of plinthite is associated with fluctuations in ground water levels, these soils are thus often associated with lower landscape positions (Sombroek, 1966; Lima et al., 2006). The development of the plinthic layer depends on the accumulation of sesquioxides through removal of silica and bases under hydrolysis, following the discharge of weathering products. This results in a relative accumulation of weathering resistant materials such as sesquioxides, quartz and kaolinite (Driessen et al., 2001). Absolute accumulation of these materials is also possible through alluvial or colluvial deposition. Another mechanism for plinthite formation is the segregation of iron which occurs under alternating reduction and oxidation conditions (Sombroek, 1984). Under water saturation much of the iron is in the ferrous form and therefore mobile. But this iron precipitates as ferric oxide when conditions become drier and does not re-dissolve, or only partially re-dissolves, when conditions become wetter again. In its unaltered form, plinthite is firm but can be cut with a spade. If the land is later uplifted or suffers changes in its moisture regime, however, plinthite can become irreversibly hardened to form petroplinthite.

Soils with plinthite layers are common under tropical forest vegetation, and soils with petroplinthite are most common in transitional zones between rain forests and savannas But petroplinthite can also occur in wetter areas where most of it has presumably been dislocated, hardened, transported and finally deposited as alluvial or colluvial parent material. Despite Plinthosols being found, at least to some extent across all of the Amazon Basin (Sombroek, 1966, 1984; Sombroek and Camargo, 1983) most of the Plinthosols identified in this study were in western Amazonia, where they commonly occur associated with well defined geomorphological and/or landscape characteristics (Fritsch et al., 2006). Physical characteristics of Plinthosols are usually restrictive; the soil is very compact with high bulk density and the soil structure generally weak for all horizons (Sombroek, 1984).

Two soil profiles have been chosen to illustrate lower level variations within this group. The first soil profile is a Haplic Plinthosol (Alumic, Orthodystric, Siltic) located in Acre state, Brazil (DOI-02, Fig. 8a). For this soil, exchangeable $\mathrm{Ca}$ and $\mathrm{Mg}$ are relatively high at the surface in relation to other Amazonian soils, but with Ca declining sharply to a depth of $0.4 \mathrm{~m}$, below which it remains relatively constant at about $10 \mathrm{mmol}_{\mathrm{c}} \mathrm{kg}^{-1}$ until $1.2 \mathrm{~m}$, then declining to practically zero values. Magnesium follows a different pattern, being mostly constant until $0.4 \mathrm{~m}$ deep and then sharply increasing until $1.2 \mathrm{~m}$, after which it starts to decline to practically zero values at $1.7 \mathrm{~m}$. Aluminium on the other hand, is practically absent until a depth of $0.3 \mathrm{~m}$, sharply increases until $0.7 \mathrm{~m}$ after which it increases again below $1.2 \mathrm{~m}$. This vertical distribution of cations in Plinthosols profiles mostly reflects the ongoing removal process of silica and bases
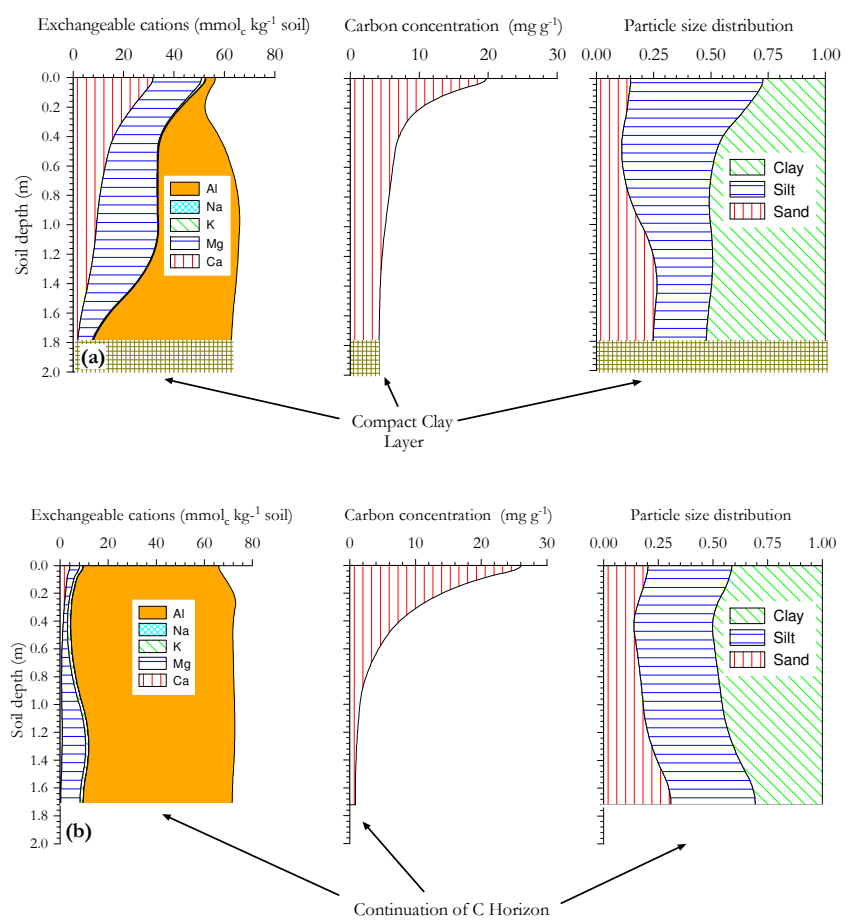

Fig. 8. Profiles of exchangeable cations, soil carbon and texture: (a) for a Haplic Plinthosol (Alumic, Orthodystric, Siltic), at Acre state, Brazil (DOI-02) and (b) for an Endostagnic Plinthosol (Alumic, Hyperdystric) in Colombia (AGP-02).

(Lima et al., 2006). Carbon does not present any special pattern apart from being relatively high in the surface layer.

The second profile is for an Endostagnic Plinthosol (Alumic, Hyperdystric) located in south-eastern Colombia, western Amazonia (AGP-02, Fig. 8b). This soil had a slightly stronger influence of slow draining water than for DOI-02, with the presence of stagnic colour patterns in the profile, similar to that described by Fritsch et al. (2006). Even though exchangeable base concentrations were much lower than DOI-02, the overall distribution pattern was virtually identical, but with higher aluminium concentrations throughout. Carbon content showed a similar pattern as for DOI-02 this also being the case for depth dependent variations in soil particle distribution.

\subsubsection{Ferralsols}

Ferralsols (Oxisols in US Soil Taxonomy) are soils that carry marks of strong weathering and desilication and typically occur in tropical, humid, free draining environments. They generally cover old geomorphic surfaces or develop over sediments that were pre-weathered from ancient regoliths (Buol, 2002; Buol et al., 2003). Ferralsols may also develop in younger materials which weather rapidly, such as basic and ultrabasic rocks and geologically old volcanic material, but these occurrences are generally of limited spatial 
importance (Buurman and Soepraptohardjo, 1980; Beinroth, 1982). Ferralsols are commonly found on stable topography of tropical regions where wet and hot climate favour intensive weathering (Sanchez, 1976). As reported by Driessen et al. (2001), and because of their extremely advanced state of pedogenic development, the weathering of the mineral fraction of Ferralsols releases only negligible amounts of nutrients or aluminium. Moreover, $\mathrm{P}$ adsorption capacity is high (de Mesquita Filho and Torrent, 1993) and the total P pool is usually small (Smeck, 1985). Also, no neo-formation of clay minerals is expected to occur. This mineral fraction is usually dominated by kaolinite and iron/aluminium oxides as goethite, hematite and gibbsite (Sombroek, 1984; Buol, 2002), a mineral assemblage that makes Ferralsols variable charge soils (Herbillon, 1980; Qafoku et al., 2004). Despite Ferralsols being chemically poor and with an acidic reaction, most have well developed physical conditions. In general they are deep, well drained soils which have low silt content, low bulk density, strong fine and very fine granular structure, and a high hydraulic conductivity (Sanchez, 1976; Richter and Babbar, 1991; Buol and Eswaran, 2000; Buol, 2002). Clays do not disperse in water and there is little osmotic swelling because the cation concentration at the surface of the kaolinitic clay is low. Ferralsols also have a considerable capacity to accumulate soil organic matter through prevalent organo-mineral interactions and their extensive depth (Dick et al., 2005; Zinn et al., 2007). Although often with a low volumetric water holding capacity (due to their low silt content), as a consequence of their favourable physical structure and considerable depth Ferralsols may be capable of storing much more water than the other more common tropical soil types, this allowing forests on such soils in eastern Amazonia to maintain physiological activity throughout extended dry seasons (Lloyd et al., 2009; Sect. 3.7)

In this study, Ferralsols were found in central and eastern areas of Amazonia as well as towards its southern border. No Ferralsols were found in the geologically younger areas close to the Andes, in agreement with the previous analysis of Sanchez and Buol (1975). As mentioned already, Ferralsols were once thought to dominate the Amazonian landscape, but this was later shown to be an erroneous perception arising from a low reliability of soil mapping in the area (van Wambeke et al., 1983; Richter and Babbar, 1991). For example, Sombroek (1966) suggested that the area covered by Ferralsols (especially the "Belterra clay" soils), was much larger than we now know to be the case. Indeed, later in his career he reported that initial assessments were overestimated, and that the areas covered by Belterra clay in western areas of Amazonia were much more limited than he first thought.

Two Ferralsol profiles are shown in Fig. 9. The first is a Geric Acric Ferralsol (Alumic, Hyperdystric, Arenic) located in Mato Grosso state, Brazil, at the southern fringe of the Amazon forest (SIN-01, Fig. 9a). Consistent with its description as "Geric", the concentration of exchangeable bases and aluminium in this Ferralsol are very low through-
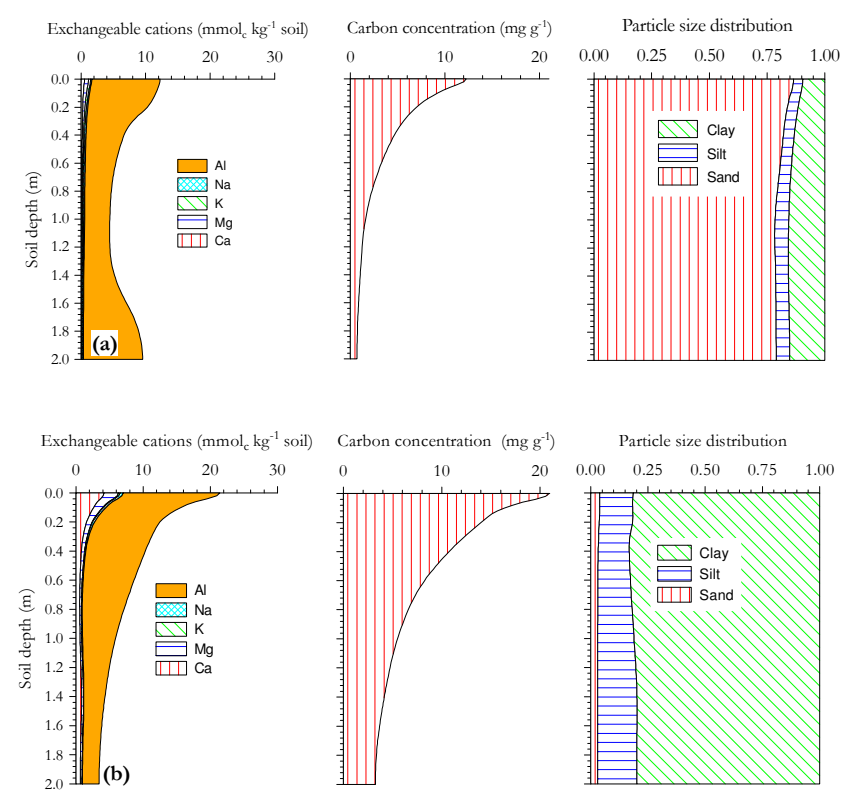

Fig. 9. Profiles of exchangeable cations, soil carbon and texture: (a) for a Geric Acric Ferralsol (Alumic, Hyperdystric, Arenic) at Mato Grosso state, Brazil (SIN-01) and (b) for a Gibbsic Geric Ferralsol (Alumic, Hyperdystric, Clayic, Xanthic) at Amapá state, Brazil (JRI-01).

out the entire profile, the only exception being the surface layer where concentrations are twice as high, most likely due to organic matter content and nutrient recycling. Nevertheless, aluminium increases towards the bottom of the profile as a result of saprolite weathering. The prefix "Acric" refers to the slight increment of clay with increasing depth, which is in turn clearly dominated by sand. Carbon content is relatively low and mirrors base cation distributions. This suggests that organic matter may be a major source for nutrients and CEC in this soil.

The other profile shown is a Gibbsic Geric Ferralsol (Alumic, Hyperdystric, Clayic, Xanthic), located in north-eastern Amazonia, Brazil (JRI-01, Fig. 9b), and an example of what is often called "Belterra clay" in the soils literature (Sombroek, 1966). As opposed to the Sinop Ferralsol, this soil has a very high clay proportion $(>0.75)$, which may be partially responsible for its relatively high carbon content (Dick et al., 2005). Although being still at the lower fertility end of the spectrum, exchangeable bases and aluminium are almost five times higher than for SIN-01. The qualifiers "Gibbsic" and "Xanthic" refer to presence of significant amounts of the mineral gibbsite and to the inherent yellow colour common to this soil, respectively. This diversity in chemical and morphological characteristics demonstrates the high variability and diversity even within the most highly weathered RSG groups. 

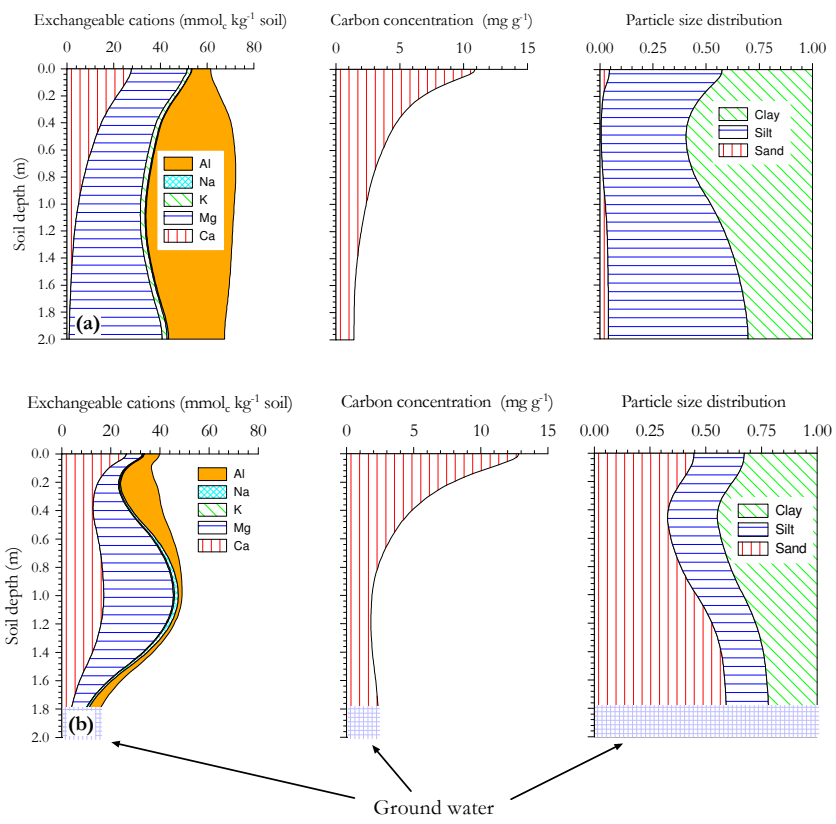

Fig. 10. Profiles of exchangeable cations, soil carbon and texture: (a) for a Haplic Alisol (Hyperdystric, Siltic) in south Peru (TAM -06) and (a) for a Hyperalic Alisol (Hyperdystric, Clayic) in Ecuador (TIP-05).

\subsubsection{Alisols}

Alisols (Ultisols in US Soil Taxonomy) are strong acid soils with high activity clays accumulating in the subsoil. They occur on parent materials which contain a substantial amount of unstable aluminium-bearing materials such as hydroxyinterlayered smectite or vermiculite. Ongoing hydrolysis of these minerals releases $\mathrm{Al}$ which then occupies more than half of the exchangeable sites. Alisol formation is confined to environments where most of the primary minerals have disappeared, and with secondary clay minerals of high activity dominating the clay complex. They have a CEC in ammonium acetate $\mathrm{pH} 7$ above $240 \mathrm{mmol}_{\mathrm{c}} \mathrm{kg}^{-1}$ clay and a base saturation of less than 0.5 in a major part of the profile. Within the tropics they usually occur on old land surfaces with hilly or undulating topography and in this study were found in Ecuador, Peru and Colombia.

Two lower level variations of Alisols have their profiles shown here. The first is a Haplic Alisol (Hyperdystric, Siltic) in south Peru (TAM-06, Fig. 10a), and the second is a Hyperalic Alisol (Hyperdystric, Clayic) in Ecuador (TIP-05, Fig. 10b).

Exchangeable $[\mathrm{Ca}]$ and $[\mathrm{Mg}]$ were relatively high in the Peruvian Alisol, along with a high exchangeable [Al]. Although Ca was mostly found near the soil surface, $[\mathrm{Mg}]$ were relatively constant until $1.2 \mathrm{~m}$, increasing steadily with depth. Most of the $\mathrm{Al}$ seems to be being released in the active clay illuviation zone, but with $\mathrm{Mg}$ weathering reaching its max- imum in the zone of increased silt content. Such vertical gradients in the nature of active weathering reflect the intermediate pedogenetic status of Amazonian Alisols.

The Ecuadorian soil has a slightly different cation and particle size profile. Calcium dominates the top $0.05 \mathrm{~m}$ of the profile, but below that both $[\mathrm{Mg}]$ and $[\mathrm{Al}]$ increase with depth to the point where $\mathrm{Mg}$ (and some $\mathrm{Ca}$ ) dominate the ECEC. Aluminium concentrations reach a maximum in the clay illuviation zone, while $[\mathrm{Mg}]$ and $[\mathrm{Ca}]$ have their increases lower down in the profile in association with an increase in coarse fraction increments. This again suggests a nonuniform weathering profile, probably in accordance with different weathering stages for the different soil minerals with depth.

Such patterns of $[\mathrm{Al}]$ and $[\mathrm{Mg}]$ reflect the pedogenetic stage of Alisols as well as the properties of 2:1 clay minerals (Driessen et al., 2001). During the early formation of Alisols, hydrolysis and transformation of primary weatherable minerals occur in the parent material with some leaching of silica. This produces a saprolite with little weatherable primary minerals and a dominance of high activity clays, most likely formed by the transformation of micas. This is followed by a redistribution of clay in the soil and the formation of an argic horizon. It is when secondary high activity clays start to weather that Alisol formation occurs and the observed cation patterns become distinguishable. High active clays are unstable in environments that are depleted of silica and alkaline and alkaline earth cations. With their weathering they release soluble aluminium and for some parent materials, iron and magnesium from the octahedral internal layers of the 2:1 clay minerals. The process of high activity clay weathering usually overlaps with clay redistribution. Clay illuviation only occurs at $\mathrm{pH}$ varying from 5 to 6.5. At lower acidic $\mathrm{pH}, \mathrm{Al}^{+3}$ becomes dominant and saturate the complex. Such Al saturation flocculates the clay and impedes further dispersion, leading to its accumulation in the profile.

Exchangeable bases in the Alisol profiles were among the highest levels found in Amazonian soils. Alisols are generally considered soils of limited fertility as they have their ECEC dominated by aluminium. But the very low fertility levels common to many Amazonian soils make them comparatively rich, occupying the more fertile end of the spectrum. Also, as is shown in Quesada et al. (2010), phosphorus supply is also generally favourable in these soils and reasonably high base cations often co-exist with the high aluminium levels. Indeed, despite their very high [Al], there is little evidence of aluminium toxicity for plants growing on such soils. For example, Gama and Kiehl (1999) found that crops growing in western areas of Amazonia did not shown serious Al toxicity symptoms; even though the soils they were growing on had exchangeable Al levels of approximately $145 \mathrm{mmol}_{\mathrm{c}} \mathrm{kg}^{-1}$. Marques et al. (2002) consider the high $\mathrm{Al}$ extracted from such soils as most likely originating from $\mathrm{Al}$ adsorbed within the structure of the 2:1 minerals such as hydroxyl-interlayered smectites. They suggest that in 
situ this "exchangeable" Al may not necessarily be in equilibrium with solution [Al], and perhaps not readily "seen" by plant roots.

The mapped distribution of Alisols (Fig. 4; see also Fig. S5 in the Supplementary Information) suggests only a limited coverage of these soils in Amazonia. But this is almost certainly an underestimate. For instance, all Alisols found in this study were found in areas outside of those identified as such in the SOTERLAC Database. In addition, soil profiles found in the RADAMBRASIL soil survey (RADAMBRASIL, 1978), in particular in the Brazilian states of Acre and Amazonas (west and southwest part of the Brazilian Amazonia), show several soil profiles which would almost certainly be classified as Alisols in the WRB system. These soils named as podzólicos vermelho amarelo álico, have high activity clays, with $[\mathrm{Al}]$ ranging from 50 to as much as $268 \mathrm{mmol}_{\mathrm{c}} \mathrm{kg}^{-1}$ and with other characteristics fulfilling all requirements for Alisols. Furthermore, there are many other soils in that region having characteristics very similar to that of Alisols, but which most likely have been converted to WRB in the SOTERLAC database as Acrisols. This is because in the translation process, such soils were generally taken to contain only low activity clays, overlooking the fact that the definition of clay activity is very different between the WRB and the Brazilian Soil Classification System as was used at the time of RADAMBRASIL. Although the WRB classifies on a per unit clay basis, the Brazilian System uses bulk soil CEC values (de Oliveira and van der Berg, 1996). Therefore many soils regarded as low activity clay in the RADAMBRASIL would probably have been considered as high activity clays soils if CEC had been corrected for clay content. Another problem regarding the conversion of clay activity from the Brazilian System is the lack of confirmation by standard chemical analysis (CEC above or below $240 \mathrm{mmol}_{\mathrm{c}} \mathrm{kg}^{-1}$ of clay, extracted by ammonium acetate pH 7 and corrected for carbon content) because such analysis were generally lacking in the RADAMBRASIL program. As an additional concern the correlation between the Brazilian and WRB systems is generally weak with this prohibiting the accurate translation of soil map legends as needed for scientific purposes (de Oliveira and van der Berg, 1996). Taken together these observations suggest that many soils described as Acrisols in SOTERLAC for the Brazilian Amazon are, in fact, Alisols as defined by the WRB.

\subsubsection{Acrisols}

Acrisols (Ultisols in US Soil Taxonomy) are considered the second most common soils in Amazonia, covering an area of approximately $2.15 \times 10^{6} \mathrm{~km}^{2}$ (Table 1 ), although as mentioned in Sect. 3.3.3, this is almost certainly an overestimate. As for Alisols, these soils are characterized by accumulation of clays in a subsurface horizon, which can be a result of several different processes, including sedimentation, lithological discontinuities, and clay migration (West et al., 1998).
They are strongly weathered acid soils with low base saturation and acid reaction (Lathwell and Grove, 1986; Richter and Babbar, 1991; West et al., 1998; Driessen et al., 2001; IUSS Working Group WRB, 2006). However, unlike Alisols, Acrisols are dominated by low activity clays with a lower CEC range $\left(<240 \mathrm{mmol}_{\mathrm{c}} \mathrm{kg}^{-1}\right.$ clay, extracted by ammonium acetate $\mathrm{pH} 7$ ). They usually evolve on acid rock of Pleistocene age or older, being notably high in strongly weathered clays which are still undergoing further degradation. The sediments that form the parent material for Acrisols often have been pre-weathered for more than one weathering cycle (West et al., 1998). Nevertheless, geomorphic studies in tropical areas have invariably shown that although Acrisols occupy younger geomorphic positions than Ferralsols, they also occur in older and more stable areas than those occupied by other soils with which they are often geographically associated (Beinroth et al., 1974; Lepsch and Buol, 1974; Beinroth, 1981; West et al., 1998). Contents of $\mathrm{Al}, \mathrm{Fe}$ and Ti oxides are comparable to Ferralsols with their clay fraction consisting almost entirely of well crystallized kaolinite and some gibbsite (Buol et al., 2003). Nevertheless, small quantities of mica, vermiculite and smectite occur in many of these soils (Sanchez and Buol, 1974; West et al., 1998). Also, as for Ferralsols, Acrisols are often reported as having variable charge clays (Uehara and Gilman, 1981; Qafoku et al., 2004)

As reviewed by West et al. (1998) the physical properties of Acrisols (and the related Luvisols, Lixisols and Alisols) often present major constraints for plant growth. Textural variation within the profile is a common problem because of water perching, limited infiltration and thus increased runoff. Moreover, the sandy/loamy surface horizons often have weak structure which favours compaction and high bulk density. These conditions in turn result in low infiltration rates, limited rooting and seedling emergence. In many of these soils, the bulk density is greater than that considered to be limiting for root proliferation due to high mechanical impedance. The presence of patches of macro-porosity and localized lower bulk density may allow root penetration into horizons of overall high bulk density, but if roots are restricted to these zones the volume of soil exploited for water and nutrients must be limited.

In this study Acrisols were found in north Peru, Venezuela and Brazil and Fig. 11 shows soil profiles for a Vetic Acrisol (Hyperdystric) located at Mato Grosso state, Brazil (ALF01). Exchangeable cation concentrations in the subsoil of this Acrisol are much lower than the surface horizon, and show little vertical variability in sub-soil nutrient concentrations other than a constant decline. Although soil carbon and exchangeable cations may show a slight increase (or lower level of decline) in the clay increment zone, sub-soil concentrations can be generalized to be uniformly low throughout the profile. This contrasts with other soils within the same morphological group such as Alisols and Lixisols, where cation concentrations may increase with depth (Figs. 10 and 

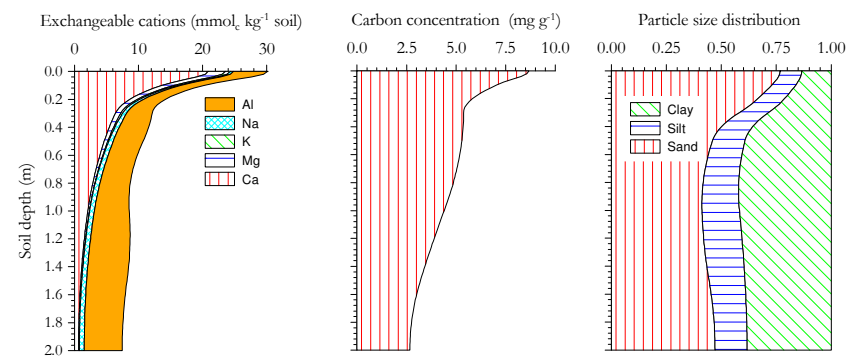

Fig. 11. Profiles of exchangeable cations, soil carbon and texture for a Vetic Acrisol (Hyperdystric) at Mato Grosso state, Brazil (ALF01).

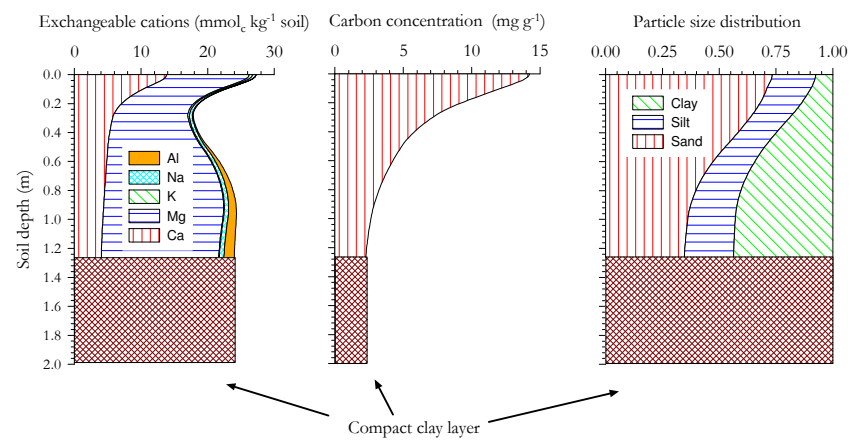

Fig. 12. Profiles of exchangeable cations, soil carbon and texture for a Cutanic Lixisol (Ferric, Hypereutric) in Venezuela (RIO-12).

12, respectively). This suggests that any contribution from active weathering of soil minerals may be small for Acrisols, which also implies that such soils are more strongly weathered than Alisols and Lixisols. At the soil surface, which is predominantly sand, the higher concentration of base cations presumably arises from the recycling of organic matter. Consistent with the "Vetic" qualifier which predicts a cation exchange capacity below the level of $60 \mathrm{mmol}_{\mathrm{c}} \mathrm{kg}^{-1}$ in some layer within the top $1 \mathrm{~m}$ of soil, this Acrisol CEC resulted below that level in all parts of the profile. However, despite lower cation concentrations than other soils with similar textural gradients, the ALF-01 Acrisol was twice as fertile as the Amazonian Ferralsol examples.

\subsubsection{Lixisols}

Lixisols (Alfisols in US Soil Taxonomy) are soils morphologically related to Acrisols, Alisols and Luvisols through the presence of argic horizons; being separated from Alisols and Luvisols by having low activity clays and low CEC. They are separated from Acrisols on the basis of their higher base saturation. For Lixisols, clay is transported from an illuvial horizon to an argic subsurface horizon that has low activity clays and moderate to high base saturation. Similar to Acrisols, Lixisols have a low CEC range $\left(<240 \mathrm{mmol}_{\mathrm{c}} \mathrm{kg}^{-1}\right.$ clay extracted by ammonium acetate $\mathrm{pH} 7$ ) but unlike Acrisols, they have base saturation of 0.5 or more. They are considered soils with advanced weathering stage but due to their parent material (often limestone or mafic rocks) base saturation is still high, with soil reaction eliminating excessive amounts of $\mathrm{Al}$ in the soil solution (Driessen et al., 2001).

Only one Lixisol was identified in this study, a Cutanic Lixisol (Ferric, Hypereutric) in Venezuela (RIO-12) and Fig. 12 shows profiles for this soil. Exchangeable bases clearly dominate the exchange complex, with $\mathrm{Mg}$ and $\mathrm{Ca}$ occupying most of the ECEC and $\mathrm{K}, \mathrm{Na}$ and $\mathrm{Al}$ present in smaller quantities. Magnesium is in clear excess to $\mathrm{Ca}$ which may be a result of parent material chemistry or immobilization of $\mathrm{Mg}$ during neoformation of secondary minerals (Thomas, 1974). The concentration of Mg increases in the clay illuviation zone, reaching its highest concentrations at the maximum clay content. Below $[\mathrm{Al}]$ and $[\mathrm{K}]$ increase slightly with a small reduction in $[\mathrm{Mg}]$. The vertical distribution of elements in this soil suggests that active weathering of soil minerals may be still taking place. Although base saturation is high in Lixisols, the ECEC itself is relatively low. For the profile examples here, this results in our Hypereutric Lixisol actually having a base cation pool which is actually less than the hyperdystric Alisols shown above.

This Lixisol was also very compact, had unweathered rocks scattered throughout, and was with a heavy structure in the B horizon. Although physical constraints are a common feature in all soils with increments in clay content, problems such as compaction, low porosity, high bulk density and top soil hardening when dry are particularly common in Lixisols (Nicou, 1974, 1975; Nicou and Charreau, 1980; IUSS Working Group WRB, 2006).

\subsubsection{Nitisols}

Nitisols (Ultisols and Oxisols in US Soil Taxonomy) are deep, red (Rhodic), well-drained tropical soils with a clayey nitic subsurface horizon that has typical polyhedric, blocky structure elements with shiny ped faces. Usually they evolve from the weathering of intermediate to basic parent rock, possibly rejuvenated by recent additions of volcanic ash. Their mineralogy is dominated by kaolinite and metahalloysite, but minor amounts of illite, vermiculite and randomly interstratified clay minerals may be present along with hematite, goethite and gibbsite. These soils are iron rich soils usually found on level to hilly landscapes (Driessen et al., 2001). In Brazil, these soils are know as terras roxas estruturadas and are often highly sought for their agricultural capabilities. Nitisols in Amazonia occupy areas where basic effusions occur (i.e. diabase and dolerite) such as in outcrops of the Guyana and Brazilian shields and some carboniferous deposits (Sombroek, 1966). For example Nitisols were reported to occur along the Trans-Amazon highway, in the upper Xingu area and in the state of Rondônia (south western Amazonia), as well as at the Raposa Serra do Sol indigenous 


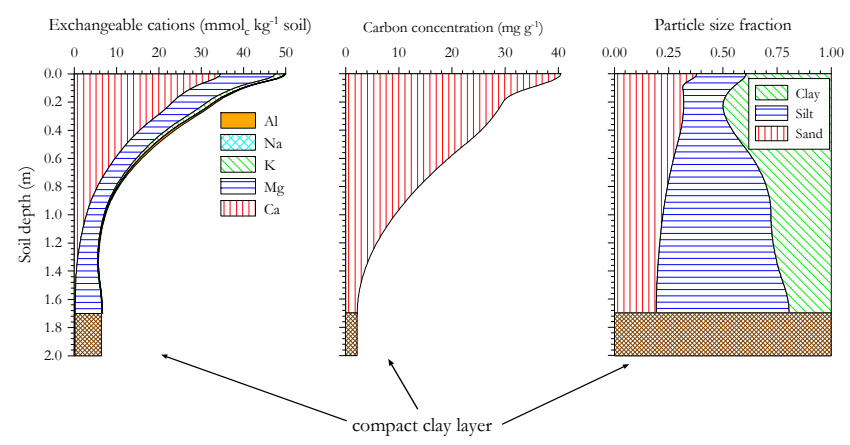

Fig. 13. Profiles of exchangeable cations, soil carbon and texture for a Vetic Nitisol (Hypereutric, Rhodic) in Bolivia (HCC-22).

reserve in northeast Roraima (Melo et al., 2010), but with a typically limited and patchy coverage (Sombroek, 1984).

The formation of Nitisols involves an initial process of ferralisation, similar to that for Ferralsols but with this still being at an early stage. The formation of Nitic properties follows with strong angular, shiny peds being developed in the subsurface horizon. This nitidisation is thought to be a result of alternating micro swelling and shrinking and produces well-defined structural elements with strong, shiny pressure faces. These soils also involve a strong biological influence, termite, ants and worm activity is thought to homogenize and create further structure and gradual diffuse horizon boundaries (Driessen et al., 2001). The cation exchange capacity of Nitisols is high compared to that of similar tropical soils such as Ferralsols, Lixisols and Acrisols. The reasons for this higher fertility lies in their characteristically high clay content and relatively high levels of organic matter. Base saturation varies from 0.1 to 0.9 in such soils (Richter and Babbar, 1991). Despite that, Nitisols also show clay increments with depth, although usually they have slightly better structure than those other soils with similar properties. This can be taken as a demonstration of the beneficial effect of organic matter and soil organisms on soil structure.

Figure 13 shows soil profiles for a Vetic Nitisol (Hypereutric, Rhodic) in Bolivia (HCC-22), the only Nitisol identified in this study. Cation profiles show that the exchange capacity of this soil is high, with [Ca] and $[\mathrm{Mg}]$ accounting for most of it. The vertical distribution of cations shows a gradual decrease with depth, with $[\mathrm{Mg}]$ remaining constant throughout the soil profile. At depths greater than $1.4 \mathrm{~m}[\mathrm{Mg}]$ becomes the dominant cation in the profile, with other cations appearing just in trace amounts. Clay increases considerably in the subsurface but then experiences a gradual decline with silt contents increasing substantially with depth. Soil carbon is generally high but remarkably so in the soil surface, showing only a small decline with depth. Vertical distribution of carbon, cations and particle size fraction are characteristic of Nitisols, where high cation exchange capacity and high base saturation is often associated with high organic matter con- tent in these soils (Richter and Babbar, 1991). At $1.7 \mathrm{~m}$ a compact clay layer with scattered rocks having vitric properties constrained sampling to that layer.

\subsubsection{Podzols}

Podzols (Spodosols in US Soil Taxonomy) are soils with whitish grey subsurface horizon, bleached by organic acids, this overlying a dark accumulation horizon with brown or black illuviated humus. Podzols occur in humid areas, in particular in the boreal and temperate zones but locally also in the tropics. In Amazonia they develop over unconsolidated weathering materials of siliceous rock which are prominent on alluvial, colluvial and aeolian deposits of quartzitic sands. They occur mostly along the Rio Negro and in the northern upper Amazon Basin (Do Nascimento et al., 2004).

During the formation of Podzols, complexes of $\mathrm{Al}, \mathrm{Fe}$ and organic compounds migrate from the surface soil to the B horizon with percolating rainwater. Podzolisation is a combination of processes, including the movement of soluble metal-humus complexes (chelates) out of the surface soil to greater depth (cheluviation), and the subsequent accumulation of $\mathrm{Al}$ and $\mathrm{Fe}$ chelates in a spodic horizon ("chilluviation"; Driessen et al., 2001). There are contrasting views regarding the formation of Podzols in the tropics, most likely with one or another occurring in different environmental conditions. Some authors advocate that Ferralsols and Acrisols (or eroded material from them) can undergo transformations and form Podzols under water saturation, via selective clay removal and lateral movement processes (Lucas et al., 1984; Chauvel et al., 1987; Bravard and Rihgi, 1989; Lucas, 1997; Dubroeucq and Volkoff, 1998; Do Nascimento et al., 2004). But Podzols can also evolve locally as a consequence of vertical pedogenic processes as described by Horbe et al. (2004). Despite their relatively small area (Table 1) Podzols are one of the most studied soil types in Amazonia (Vitousek and Sanford, 1986), with a great variety of studies investigating their characteristic infertility and associated tight nutrient cycling (Went and Stark, 1968; Jordan and Herrera, 1981; Jordan, 1989). A comprehensive review of formation and characteristic of Amazonian Podzols is given by Do Nascimento et al. (2004).

Generally these soils have severe acidity, high [Al], low chemical fertility and unfavourable physical properties. The organic matter profile of Podzols usually shows two areas of concentration, one at the surface and one in the spodic horizon, but often erosion of surface horizons can expose the albic horizon (a low organic matter, bleached layer) resulting in only one zone of increased organic matter. Usually, high concentrations of $\mathrm{Al}$ or $\mathrm{Fe}$ occur in conjunction with the spodic horizon, this reflecting the concentrations of metalhumus chelates in this zone. The C:N-ratio is typically as high as 50 in the surface horizon, and nutrient levels in Podzols are low as a consequence of a high degree of leaching (Buol et al., 2003; Quesada et al., 2010). Plant nutrients are 


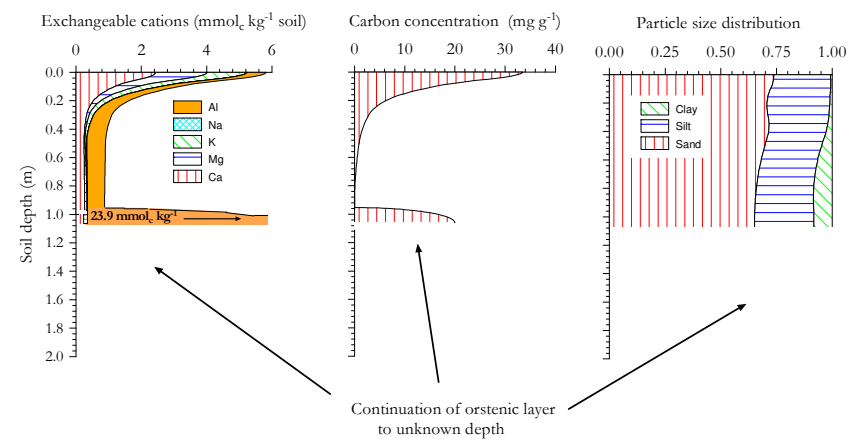

Fig. 14. Profiles of exchangeable cations, soil carbon and texture for a Ortsteinc Podzol (oxyaquic) in Colombia (ZAR-01).

concentrated in the surface horizon where impressive root mats often occur (Jordan and Herrera, 1981). Nutrient economy in these soils is highly dependent on the recycling of elements which are released by decomposing organic debris.

In hydromorphic Podzols, dissolved organic matter bound with $\mathrm{Al}$ is often transported laterally as shallow groundwaters restrict vertical transport within the soil. These hydromorphic Podzols with lateral water flow are inevitably associated with "black water" rivers and lakes in boreal, temperate and tropical areas (Driessen et al., 2001). The formation of a hardpan by illuviated sesquioxides and organic matter (ortsteinic) is common in podzols where there is periodic water stagnation in the soil, either in the B horizon or below it. Water movement through the soil may be restricted, even in upland areas, if such a dense illuviated horizon or an indurate layer is present (Buol et al., 2003).

In this study, Podzols were found in Brazil, Colombia and Venezuela, usually supporting forests, with a low above ground biomass. Together with the Arenosols (Sect. 3.5.1) they are the most infertile soils in Amazonia and Fig. 14 shows profiles for one Ortsteinc Podzol (oxyaquic) in Colombia (ZAR-01). The vegetation over this soil is locally called Varrillal which translates to "land of twigs"; it is a stunted forest in which thin and very short trees are abundant. An impressive root mat covers the soil, almost no roots were observed inside the mineral soil itself. The exchangeable bases are very low with most found in the very topsoil. Aluminium constitutes most of the ECEC and an association between base cation concentrations and soil organic matter is obvious; most if not all nutrient exchange must occur in the root mat which keeps the remaining nutrients held within the system. At the start of the ortsteinic layer at approximately $1 \mathrm{~m}$ deep, aluminium concentration increased abruptly as did the carbon content. This is taken to reflect the composition of the ortsteinic layer where Al-humus chelates act as cementing substances.

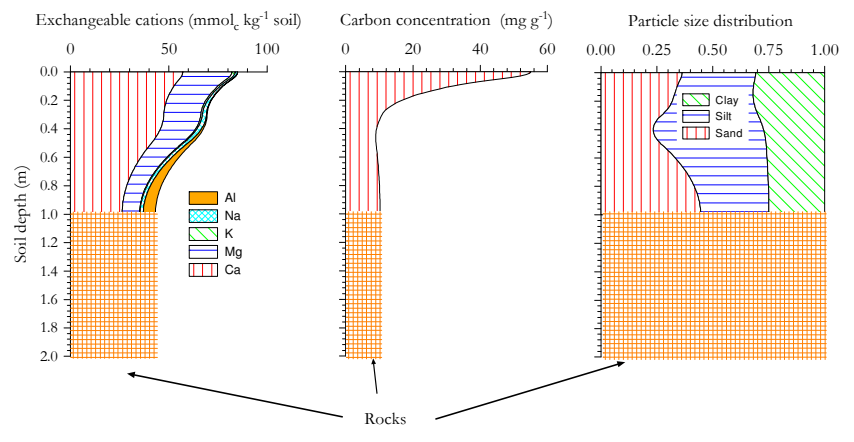

Fig. 15. Profiles of exchangeable cations, soil carbon and texture for a Haplic Fluvisol (Orthodystric) in Ecuador (JAS-05).

\subsection{Soils conditioned by topography and drainage}

\subsubsection{Fluvisols}

Fluvisols (Entisols-Fluvents in US Soil Taxonomy) are genetically young soils formed on sediments of alluvial origin (Buol et al., 2003). Their principal morphologic characteristic is the presence of stratification and weak horizon differentiation (Driessen et al., 2001; IUSS Working Group WRB, 2006). They are usually shallow with their fertility strongly dependent on the nature of the material deposited (Irion, 1984; Sanchez, 1976). The only Fluvisol identified in this study (JAS-05) had been derived from lateral movements of the Napo River in Ecuador. Fluvisols are a common soil group in Amazonia, especially in its western parts where they occur over large floodplains of recent alluvial origin (Sombroek, 1984; Fig. 4).

Soil profile data for our Haplic Fluvisol (Orthodystric), is shown in Fig. 15. Exchangeable bases were relatively high but with low [Al]. Despite such high nutrient concentrations, this soil was still classified as Orthodystric as its base saturation extracted by ammonium acetate $\mathrm{pH} 7$ was only 0.21 , a problem already discussed in Sect.2.2. The carbon profile showed a relatively high $[\mathrm{C}]$ near the surface, followed by a decline until $0.4 \mathrm{~m}$, rising again at depth, this also being associated with irregular variations with depth for the particle size distributions. These stratification patterns probably reflect the discrete sediment deposition events which are typical for this soil type. The lower portion of the soil profile consisted of rounded rocks similar to that found at the margins of the Napo River itself, suggesting that the area occupied by today's soil was once under or at the river margin. Above that, two different depositional layers were clearly identifiable, with the lower buried soil layer having a relatively higher $[\mathrm{C}]$ than the layer immediately above. 


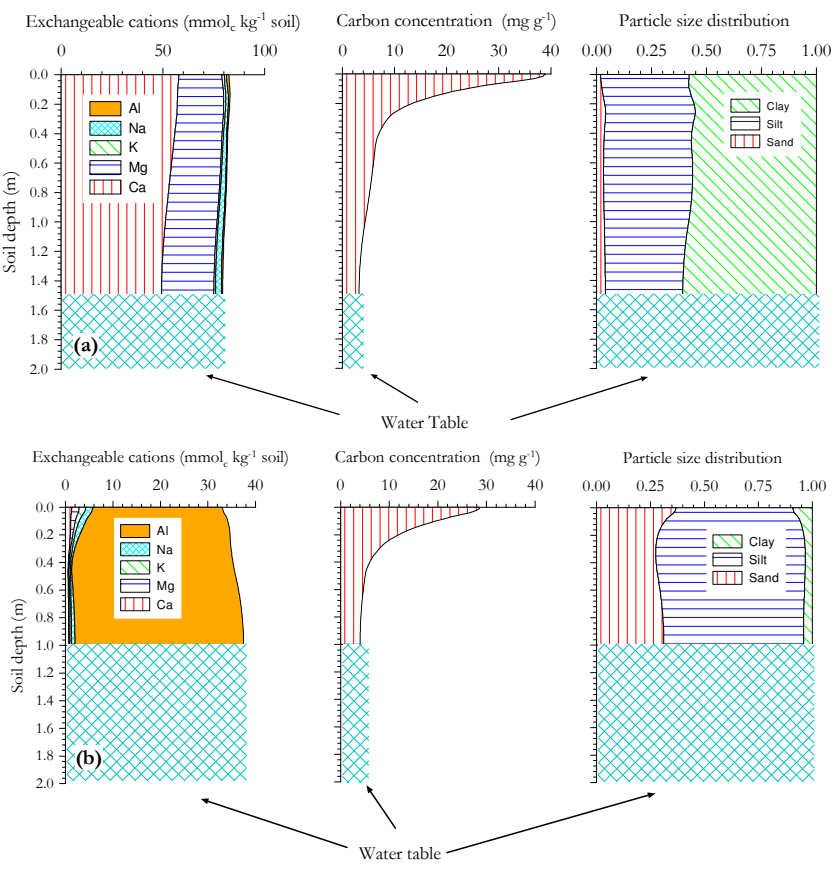

Fig. 16. Profiles of exchangeable cations, soil carbon and texture for (a) a Haplic Gleysol (Orthoeutric, Siltic) in Ecuador (TIP-03) and (b) for a Haplic Gleysol (Alumic, Hyperdystric) in Colombia (ZAR-02).

\subsubsection{Gleysols}

Gleysols (Entisols-Aquents in US Soil Taxonomy) are soils from wetlands which remain saturated for long enough periods to allow formation of gleyic colour patterns; these considered to be evidence of reduction processes with or without segregation of iron (Driessen et al., 2001; IUSS Working Group WRB, 2006). They usually occupy lower positions in the terrain and are linked to shallow groundwater. Such soils are formed under excessive wetness at shallow depths for some period of the year or throughout the year. Low redox conditions brought about by prolonged soil saturation in the presence of dissolved organic matter induce the reduction of ferric iron to mobile ferrous compounds (Osher and Buol, 1998). When iron compounds are mobilized and removed, the soil material shows its own true colours, which normally have a low hue. This is the reason why permanently saturated gleyic subsoil layers have neutral, whitish/greyish or bluish colours (Driessen et al., 2001; Buol et al., 2003). Gleysols occurring in land depressions or at the bottom of slopes are usually comparatively fertile compared to adjacent soils as they tend to have a finer texture, slower organic matter decomposition rates and an alluvial or colluvial influx of nutrients.

Gleysols are common soils in Amazonia (Sombroek, 1966, 1984; Sanchez, 1976; Fig. 4) and in this study they were found in Peru, Ecuador and Colombia. Two soil profiles are shown here, these representing the two ends of the fertility spectrum. Figure 16a is for Haplic Gleysol (Orthoeutric, Siltic), located in Ecuador (TIP-03). For this soil, exchangeable bases were very high throughout the profile, at least by Amazonian standards, with [Ca] being particularly high, and Al saturation low. Carbon content was, however, only prominent at the very surface of the soil in the layer with some soil structure apparent. Below that depth, $\mathrm{C}$ contents are low and constant throughout the profile. Particle size fractions suggested a silty clay, changing to clay in some soil layers.

The second profile is for a Haplic Gleysol (Alumic, Hyperdystric) in Colombia (ZAR-02, Fig. 16b). Unlike TIP-03, exchangeable bases were low but with the CEC quite high and dominated by [Al]. Despite surface soil $\mathrm{C}$ being not as high as in the first Gleysol example, the overall distribution pattern of $\mathrm{C}$ is similar in both soils. Nevertheless, in contrast to TIP-03, the clay fraction was very small with silt and sand predominating. Soil particle size was constant throughout the profile, having a sandy loam texture.

From the above it is evident that, as for Cambisols (Sect. 3.1.2), Gleysols can encompass soils of a wide range of fertilities and textures and with incipient weathering due to perching water often resulting in little differentiation throughout the profile. For most Gleysols physical properties are restrictive; both by water saturation and incipient development of subsurface horizons. Although such soils are usually deep, effective rooting depths are often limited, this being due to constraints imposed by a high bulk density, limited oxygen supplies, soil compactness and water saturation.

\subsubsection{Umbrisols}

Umbrisols (Umbric Great Groups in US Soil Taxonomy) are a reference group of young soils thought to be restricted to high altitudes, and accordingly are not even mapped in the SOTERLAC database as occurring in Amazonia. The main characteristic of these soils is the development of an umbric surface horizon, without any other mature diagnostic subsurface horizon. Organic matter is thought to accumulate in such soils as a result of low temperatures. They may share some characteristics with Cambisols but a higher position in the classification key gives them prevalence. An umbric horizon is a thick, dark coloured surface horizon with low base saturation and rich in organic matter. No other diagnostic horizon may be present apart of an anthropedogenic, an albic or a cambic horizon (Driessen et al., 2001).

Although at odds with the idea of having an umbric layer arising only as a result of lower temperatures in mountainous regions (IUSS Working Group WRB, 2006), two adjacent profiles in the lowland forests of Bolivia were classified in this work as Umbrisols and Fig. 17 shows profiles for LSL01, an Endogleyic Umbrisol (Alumic, Hyperdystric). Following Umbrisol classification requirements, dark organic matter dominates the surface soil. Exchangeable bases are low, with the CEC dominated by Al with the particle size 


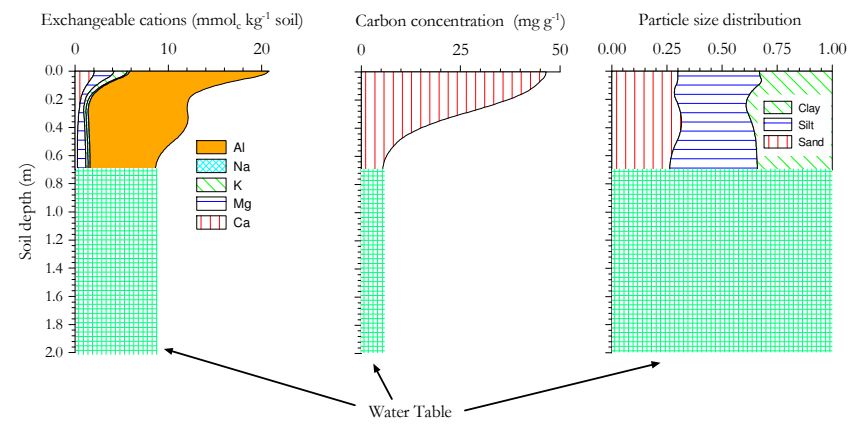

Fig. 17. Profiles of exchangeable cations, soil carbon and texture for a Endogleyic Umbrisol (Alumic, Hyperdystric) in Bolivia (LSL$01)$.

profile showing a dominance of clay loam. Both clay and sand showed some increment starting at $0.5 \mathrm{~m}$ but it is impossible to tell where they extended as our sampling stops at $0.7 \mathrm{~m}$ due to groundwater being reached.

Although misclassification cannot be ruled out because our sampling profile was limited in depth by groundwater, the WRB soil classification system led unequivocally to us keying these soils out as such. If not Umbrisols, these soils in Bolivia would probably be classified as Cambisols or perhaps Gleysols. A similar situation is reported by Schad et al. (2001), who classified several soils as Phaeozems in lowland Bolivia. Phaeozems are fertile soils with mollic or umbric surface horizons, which had been thought to be exclusively associated to the steppes of temperate regions. As a new group in the WRB system, it seems likely that some Umbrisols apparently outside the central concept and characteristics will appear. It is thus likely that some additional characteristics will be required to fully separate these soils into meaningful sub-categories.

\subsection{Soils conditioned by parent material}

\subsubsection{Arenosols}

Arenosols (Entisols-Psamments in US Soil Taxonomy) are poorly studied soils, most likely a consequence of their limited agricultural importance. This is despite their considerable worldwide extent, covering 900 million ha globally compared with 700 million ha of Ferralsols (Hartermink and Huting, 2008). In Amazonia, their coverage area is much lower $(0.03$ of the area, approximately 20 million ha, Table 1). Arenosols are characterized by coarse textures which must be derived from sand rich parent materials transported by wind, water or in some cases, locally weathered and deposited in colluvial zones through selective erosion (Driessen et al., 2001; Buol et al., 2003; IUSS Working Group WRB, 2006). Arenosols are generally weakly developed, with little horizon differentiation. Characteristic properties of such soils are high water permeability, low water holding capac-
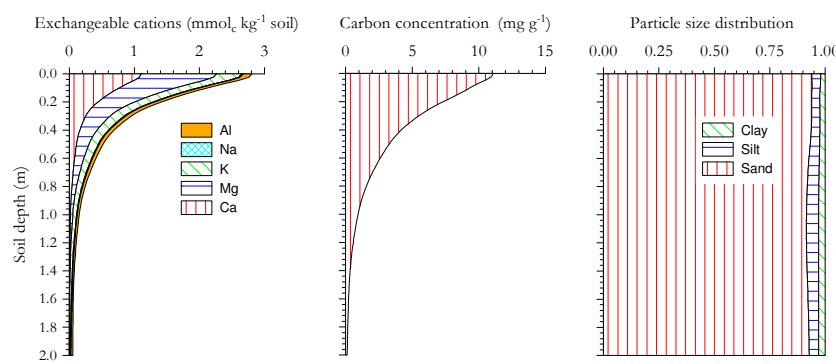

Fig. 18. Profiles of exchangeable cations, soil carbon and texture for a Haplic Arenosol (Hyperdystric) in north Peru (ALP-21).

ity, low specific heat, and often minimum nutrient contents (van Wambeke, 1992). They also have a limited potential to supply nutrients through weathering and thus almost all nutrient supply must come from mineralization of organic matter and/or atmospheric deposition. In a recent study, Hartermink and Huting (2008) showed that cation exchange capacity in 150 Arenosols of Southern Africa varied markedly with small increments in clay content, CEC ranged from about 10.0 to $90.0 \mathrm{mmol}_{\mathrm{c}} \mathrm{kg}^{-1}$, varying linearly along a change in clay content of only 0.12 . A similar relationship was also found in soil carbon content which varied from about 0.5 to $12 \mathrm{~g} \mathrm{~kg}^{-1}$ for a similar change in clay. Carbon concentrations and CEC were also linearly related suggesting that organic matter is the major source of nutrients. However, the African Arenosols studied seem to be much more fertile than those we have observed in the Amazon Basin. For example, the CECs for both Arenosols found in this study were less than $4.0 \mathrm{mmol}_{\mathrm{c}} \mathrm{kg}^{-1}$. Although these soils often support savannas or grasslands in the tropics, they are also found under short forests and even under lowland tropical forests in Amazonia, (Sanchez, 1976; Sombroek, 1966, 2000). Sometimes, Arenosols are in fact giant Podzols which key out as Arenosols because the diagnostic spodic horizon is too deep to allow their classification as Podzols. In places where evaporative demand exceeds water supply, water deficit is considered a major problem for vegetation (Sanchez, 1976), although roots are often found in these soils extending to considerable depths.

Figure 18 show soil profiles for a Haplic Arenosol (Hyperdystric), a typical "white sand" of northern Peru. Exchangeable bases and aluminium are extremely low with most of the cations pool present at the very upper soil layers, most likely reflecting nutrients held on soil organic matter. Fertility of such soils is extremely dependant on biological cycles which maintain nutrients held in the biomass (Sombroek, 1966) with soil carbon concentration also very low and declining dramatically with depth. The low carbon and cations concentrations both reflect the characteristic coarse soil texture of Arenosols. 


\subsubsection{Andosols}

Andosols (Andisols in US Soil Taxonomy) are dark soils developed on volcanic materials. They mostly occur in undulating to mountainous zones in humid, arctic to tropical regions and under a wide range of vegetation types. They are formed through rapid weathering of porous volcanic material which results in accumulation of stable organo-mineral complexes and short range order minerals such as allophane, imogolite and ferrihydrite (Richter and Babbar, 1991; Shoji et al., 1993; Driessen et al. 2001). Their coverage in Amazonia is small and mostly restricted to mountain regions in the Andes, usually occurring under cloud forests. Therefore, Andosols should not be thought of as common soils for lowland tropical vegetation.

Following the description in Driessen et al. (2001), these soils are characterised by the presence of either an andic horizon or a vitric horizon. An andic horizon is rich in allophanes and similar minerals, or aluminium humus complexes whereas a vitric horizon contains volcanic glass. Andosol formation depends essentially on rapid chemical weathering of porous, permeable, fine-grained mineral material in the presence of organic matter. The high [Al] protects the organic component of the $\mathrm{Al}$ humus complex against biological decay. The mobility of these complexes is limited because rapid weathering yields sufficient $\mathrm{Al}$ and $\mathrm{Fe}$ to produce complexes with a high metal/organic ratio which have moderate solubility. Together, the low mobility and high resistance to biological degradation promotes an accumulation of organic matter in the topsoil which culminates in the formation of a melanic surface horizon with high organic matter content. The average organic matter content of the surface horizon is about $80 \mathrm{mg} \mathrm{g}^{-1}$ but the darkest profiles may contain as much as $300 \mathrm{mg} \mathrm{g}^{-1}$ organic matter. Soil bulk density is usually low in such soil, a consequence of increments in the pore fraction as weathering advances. The dominant type of clay changes over time, particularly in the subsoil, as allophane and imogolite are transformed to other clay minerals such as halloysite, kaolinite or gibbsite. Aluminium from the humus complexes also gradually becomes available, with ferrihydrite eventually turning into goethite. Eventually, Andosols may evolve into a more mature soil, such as a podzol, or a soil with ferric properties or clay illuviation (Driessen et al., 2001).

Only one Andosol was identified in this study, a Silandic Andosol (Hyperdystric, Siltic), under a sub-montane forest near the Sumaco volcano, Ecuador (SUM-06). For this soil, exchangeable cations were relatively high at the surface (Fig. 19) declining dramatically with depth. Soil carbon reached nearly $200 \mathrm{mg} \mathrm{g}^{-1}$ at the very topsoil in association with exchangeable $\mathrm{Al}$, possibly indicating dominance of $\mathrm{Al}$ humus complexes at that depth. Nevertheless, the organic matter concentration was reasonably high throughout the profile. The finer fractions of the soil decreased almost steadily with depth, most likely reflecting the influence of

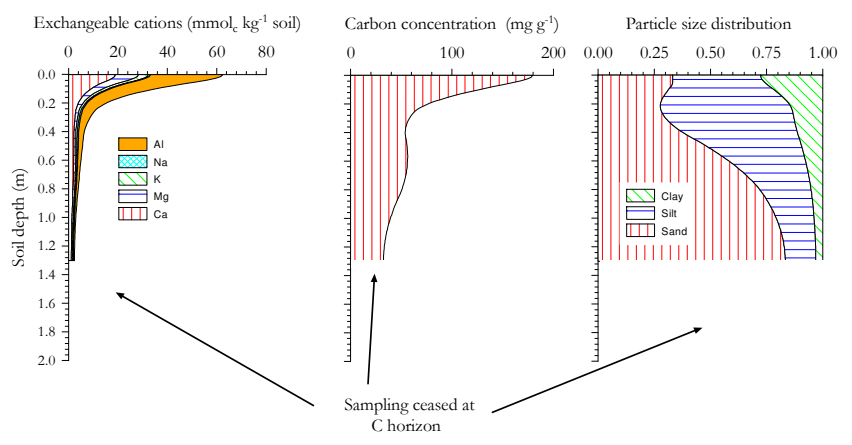

Fig. 19. Profiles of exchangeable cations, soil carbon and texture for a Silandic Andosol (Hyperdystric, Siltic) near the Sumaco volcano, Ecuador (SUM-06).

low weathering levels and with the subsurface horizons still lacking development.

\subsection{Other soils}

A few soil groups known to occur in the humid tropics were not represented in this study, and because of their limited coverage are not discussed here. These include the Solonchaks, Solonetzs, Phaeozems, Regosols, Histosols and Luvisols. The first two soil groups are unlikely to be found under forest vegetation in Amazonia as Solonchaks are imperfectly drained, salt rich soils typical of coastal regions with the Solonetzs being another Na-rich soil group. Phaeozems are fertile, wet soils characterised by an extensive accumulation of organic matter and again with only a very limited cover in Amazonia.

On the other hand, Regosols, Histosols and Luvisols probably have a wider distribution beneath Amazonian vegetation. Regosols are classified as suborders Orthents and Psamments in the Soil Taxonomy and are thin soils derived from unconsolidated material and lacking diagnostic horizons. They are thus soils with incipient development. Histosols are soils with $>0.30$ organic matter at the surface, usually occurring in Amazonia only in landscape depressions and wetlands, mostly appearing in small patches associated with other soils. Luvisols are similar to Alfisols in the Soil Taxonomy system; their principal characteristics are clay illuviation and both a high ECEC and a high base saturation. Despite their limited range in the moist tropics of South America this makes them very valuable for agriculture and also for ecological studies (Richter and Babbar, 1991; Sanchez and Buol, 1975).

Man made soils have not been included here as this work intended to review only undisturbed forest soils in Amazonia. There is however evidence that such soils often occur under forest vegetation in localities where ancient human communities have existed (Posey and Balick, 2006). Of the man made soils, the Amazonian black earths (Anthrosols or Terra Preta do Indio) have received the most attention due 


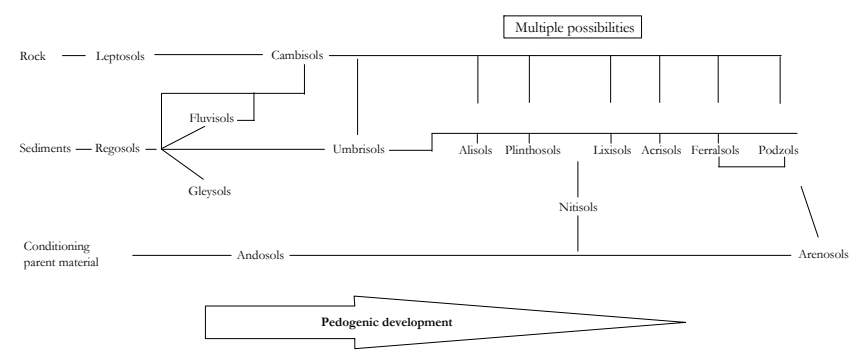

Fig. 20. Simplified scheme for soil development in Amazonia.

to their high non-labile soil carbon contents. A comprehensive description of Amazonian black earths can be obtained in Lehmann et al. (2003) and Glaser and Woods (2004).

\subsection{Linking WRB reference soils groups to a general scheme of soil genesis}

From the above analysis, it is clear that the soils of Amazonia encompass a considerable diversity with observed variations in physical and chemical properties strongly associated with state of pedogenic development (Quesada et al., 2010). To contextualize this diversity in a soil evolutionary frame, a scheme of pedogenic development is thus proposed (Fig. 20). This ordination of the soils was made on the basis of their genetic, chemical and morphological characteristics, typical mineralogy and interpretation of the effects of local soil forming factors.

In the very early stages of soil formation, different parent materials give rise to what should be the first source of variability in soils. The first soils to evolve from rocks are thus considered to be the Leptosols which are very shallow soils, with incipient weathering of parent material. If the weathering of the subsurface soil occurs at higher rates than surface erosion, then such soils will most certainly reach a Cambisol stage (Buol et al., 2003). Nevertheless, many soils in Amazonia develop over deposited sediments and if drainage conditions are good, such sediments would most likely evolve to a Regosol stage, equivalent to Leptosols but of a sedimentary origin. After that, different paths of soil formation are postulated to occur depending on drainage extent. If sediments are water saturated for a long time Gleysols may be formed. These can thus be considered to be genetically young soils, with very little profile development and with this condition being maintained by continuous or periodic water saturation. But for sediments deposited sequentially and where this has been in the not too distant past, then Fluvisols occur. Although Fluvisol drainage conditions are usually better than Gleysols, seasonal saturation of the subsoil still maintain such soils at low level of pedogenic development.

Moisture regime and landscape position are possibly the most important factors determining soil formation at these early stages, and development towards other soil types may demand some drastic changes in the landscape and water regime (Fritsch et al., 2006). Nevertheless, provided that sufficient changes in drainage occur, Gleysols probably should evolve into more mature soils, most likely involving a Cambisol stage, followed by the development of argic or plinthic horizons. Fluvisols may also develop to Cambisols once they are no longer exposed to new depositional events. However, changes in drainage may also occur increasing water saturation in the profile which could result in transformation of iron to ferrous compounds and formation of Gleysols. Also, some types of parent material can lead to specific soil forms. For instance volcanic material almost invariably leads to the formation of Andosols. The only Andosol found in this study had the characteristics of a poorly developed soil, thus it was assumed to have a transient condition equivalent to an intermediary position close to Cambisols.

Cambisols are soils showing early signs of horizon differentiation usually occurring on steep hill slopes in Amazonia, but unless erosion keeps pace with subsoil weathering, they will evolve and give rise to more mature soil groups (Buol et al., 2003). The most important factors influencing Cambisol transformations are topography position and parent material; this then leading to a large variation in the relative magnitudes of the many processes and mineralogical reactions giving rise to distinct routes of soil formation. Cambisols are thus soils in a transitional state, occurring prior to the development of any spodic, ferralitic or argic horizons (Buol et al., 2003).

Umbrisols are typical of cool mountain landscapes where temperature controls over decomposition allow the formation of thick humus layer on the topsoil (umbric horizon). Usually there is no other diagnostic horizon present but cambic horizons may be present (Driessen et al., 2001). In this study, some lowland soils in Amazonia did key out as Umbrisols, as this group has priority over Cambisols which would probably be their classification if the latter were higher up the classification tree. In the pedogenic scheme here Umbrisols are tentatively placed after Cambisols, this placement considering their incipient subsurface development and the development of umbric horizon.

The intermediate - mature phase of soil development includes some soils with similar weathering levels which make separation more difficult than for the earlier stages. Some of these soils share great morphological similarities and thus their differentiation was based on mineralogy and clay activity, cation exchange capacity and characteristics of nutrient release in vertical soil profiles, this being considered together with soil morphology. Alisols are high CEC soils in which high activity clays accumulate in a subsurface horizon. Their mineralogy is dominated by $\mathrm{Al}$ bearing secondary clay minerals such as smectite and vermiculite. Such minerals are formed from the alteration of micas, most commonly found in Cambisols, suggesting Alisols have some developmental proximity to this soil type. Also active weathering of 2:1 high activity clay minerals most likely releases aluminium and some base cations to the soil solution, this varying with 
soil depth. Although the presence of clay illuviation places Alisols at a higher evolutionary stage than the previously discussed soils, their higher CEC, high activity clay mineralogy and vertical patterns of weathering/nutrient release suggests that Alisols have a lower level of pedogenic development than the other intermediate soil groups.

Plinthosols follow a somewhat different route of formation, being strongly influenced by fluctuation of groundwater, most likely evolving from Gleysols, Fluvisols and some Cambisols with aquic properties. They are placed after Alisols due to their lower CEC but still have similar chemical characteristics, a placement which is also supported by their mineralogy which tends towards the formation of kaolinite and sesquioxides. Plinthosols are tentatively separated here from Nitisols, Lixisols and Acrisols, by the ongoing removal of silica and bases and subsequent segregation of iron.

Nitisols can be placed between Plinthosols and the remaining soils with argic horizon due to their mineralogy and intermediate age morphologic characteristics and, compared with Lixisols and Acrisols, differentiated on the basis of weathering of parent material. This still seems to be supplying adequate amounts of exchangeable bases for Lixisols, but with Acrisols not showing any sign of active mineral weathering in their subsoil.

Acrisols are, however, easily separated from Ferralsols on the basis of their contrasting morphologies, mineralogy and chemistry. For example, unlike Acrisols, Ferralsols do not have significant signs of clay illuviation, and have reached complete desilication and transformation of clay minerals toward kaolinite and $\mathrm{Fe}$ and $\mathrm{Al}$ oxides. Ferralsols might be the final stage of weathering in many conditions, but further transformation to Podzols via selective clay removal under water saturation and lateral movement processes has been suggested (Lucas et al., 1984; Chauvel et al., 1987; Bravard and Rihgi, 1989; Lucas, 1997; Dubroeucq and Volkoff, 1998). Usually, Ferralsols show no tendency to develop an elluvial horizon but they may potentially transform to Podzols if iron compounds are removed, and the clay is decomposed by ferrolysis under conditions of periodic water stagnation. This might occur on colluvial deposits transported from Ferralsols down slope. Nevertheless, as already discussed, Podzols can also develop as a consequence of vertical pedogenic processes, following the formation of white sands (Horbe et al., 2004).

Arenosols usually have depositional origin but can also be formed under weathering of quartz rich rocks. As conditioned by their parent material, they show very little horizon differentiation and for that reason are often considered young soils (IUSS Working Group WRB, 2006). Nevertheless, many Arenosols in the Amazon Basin seem to derive from old reworked sediments originating from the Guyana shield (Fittkau, et al., 1975). Their soil chemistry is also characteristic of the "terminal stages" of pedogenesis (Quesada et al., 2010) and for those reasons are assumed to belong to older development surfaces.

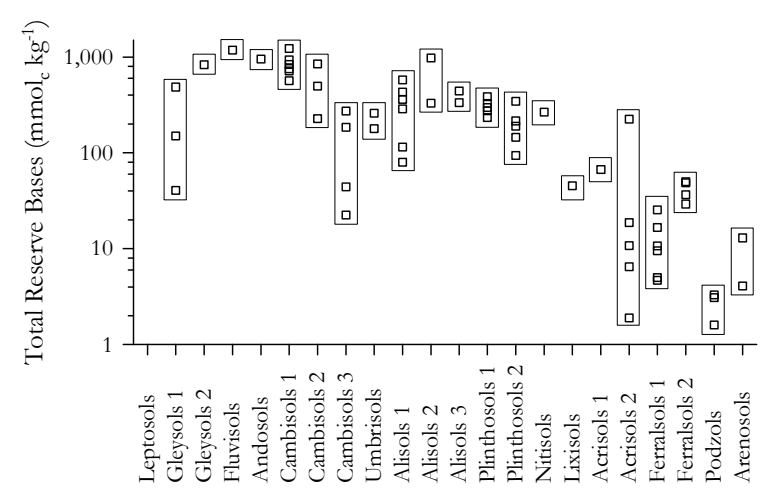

Reference Soil Group

\begin{tabular}{|c|c|c|c|}
\hline RSG & Subgroup & Prefixes & Suffixes \\
\hline Gleysols & 1 & Haplic & Hyperdystric Alumic \\
\hline Gleysols & 2 & Haplic & Orthoeutric \\
\hline Cambisols & 1 & Plinthic, Vertic or Haplic & Orthoeutric \\
\hline Cambisols & 2 & Stagnic or Vetic & Hyperdystric \\
\hline Cambisols & 3 & Haplic & Hyperdystric Alumic \\
\hline Alisols & 1 & Haplic & Hyperdystric \\
\hline Alisols & 2 & Hyperalic & Hyperdystric \\
\hline Alisols & 3 & Haplic & Hyperdystric Alumic \\
\hline Plinthosols & 1 & Endostagnic & Hyperdystric Alumic \\
\hline Plinthosols & 2 & Haplic & Hyperdystric Alumic; Orthodystric Alumic \\
\hline Acrisols & 1 & Vetic & Hyperdystric \\
\hline Acrisols & 2 & Vetic & Hyperdystric Alumic \\
\hline Ferralsols & 1 & Geric & Hyperdystric Alumic \\
\hline Ferralsols & 2 & Geric Acric & Hyperdystric; Hyperdystric Alumic \\
\hline
\end{tabular}

Fig. 21. Relationship between the axis of soil development and the chemically based weathering index Total Reserve Bases $\left(\Sigma_{\mathrm{RB}}\right)$. Details for World Reference Base lower level classification are also given.

Figure 21 shows the relationship between the suggested axis of pedogenic development and a chemically based weathering index (Total Reserve Bases, $\Sigma_{\mathrm{RB}}$ ), which is taken to be a good proxy for the amount of weatherable mineral remaining (Delvaux et al., 1989). To account for variations within the soil groups, each Reference Soil Group was further divided into subgroup types representing the principal distinctions in the lower taxonomic levels (the table with Fig. 21 gives taxonomic details for RSG lower classification levels). Noting the logarithmic $y$-axis, this chemical weathering index showed good agreement with the proposed nature of the soil age gradient. Soils with lower pedogenic development all had high levels of $\Sigma_{\mathrm{RB}}$, with the highest values occurring in Cambisols, Fluvisols and Gleysols. Beyond these classes $\Sigma_{\mathrm{RB}}$ declines gradually as pedogenic development increases, reaching its lowest values in the Podzols. Such changes along the pedogenic gradient are likely to be associated with relative concentration of weatherable minerals, changes in mineral assemblage through processes such as desilication, neoformation and kaolinization and changes in surface area and charge characteristics associated with 
changes in the mineral matrix (Uehara and Gilman, 1981). Variations within soil lower levels were also found, and in general, the nomenclature of the lower taxonomic levels was successful in grouping similar soils. Within each soil group, not only do the prefixes for the lower levels characterize individual morphological features but on some occasions they were found to also help to differentiate soils in terms of fertility and weathering level. For instance, Ferralsols named with suffix "Geric Acric" had higher $\Sigma_{\mathrm{RB}}$ than the (just) "Geric" ones, as did "Endostagnic" Plinthosols in relation to "Haplic Plinthosols". This was independent of sharing the same fertility suffixes and indicates that the chemical and morphological characteristics described by the WRB suffixes and prefixes may reflect meaningful and functional intergrades of weathering and possibly differences in parent material. However, other subgroups in Alisols and Acrisols appeared to be less divergent in relation to weathering with no clear differentiation in $\Sigma_{\mathrm{RB}}$.

In the World Reference Base a more precise level of fertility is usually described by qualifier suffixes which, in the case of this study, included "Orthoeutric", "Hyperdystric" and "Alumic Hyperdystric". This was particularly informative for Cambisol group, where a distinct gradient was observed among the three lower level soils. Levels of fertility and weathering in these soils were clearly separated by the different suffixes, irrespective of the prefix variations associated with morphological characteristics.

Also, during the process of soil classification, it was found that soils with relatively high levels of fertility were still classified as "Hyperdystric" and with the informative differentiation indicating exceptionally infertile soils only made through the suffix "Alumic Hyperdystric", indicating a clear dominance of aluminium over exchangeable bases. Therefore, soils with the qualifier suffix "Hyperdystric" (when not associated with suffix Alumic) can actually be taken as constituting relatively fertile soils in the Amazonian context (Quesada et al., 2010).

The diagram in Fig. 20 shows a simplified route for soil pedogenic development. But actual soil formation and evolution is, of course, far more complex. Short cuts in the soil formation process are known to occur. Moreover, rejuvenating processes can potentially change the direction of soil development. On other occasions, the saprolite from which soils evolve might already have been well weathered during ancient times, thus leading to the direct formation of highly weathered soils such as Ferralsols (Buol et al., 2003). Soils can also themselves become the parent material for other soils if dramatic changes in weather or topography occur. As well, they can be buried, transported and re-deposited, and even disappear if totally eroded. Nevertheless, irrespective of development pathway, soils tend to change their characteristics through time, and so will ultimately develop to genetically mature forms. Clear changes in morphology, chemistry and mineralogy will occur during this process and such variation ultimately exerts a profound effect over the vegetation
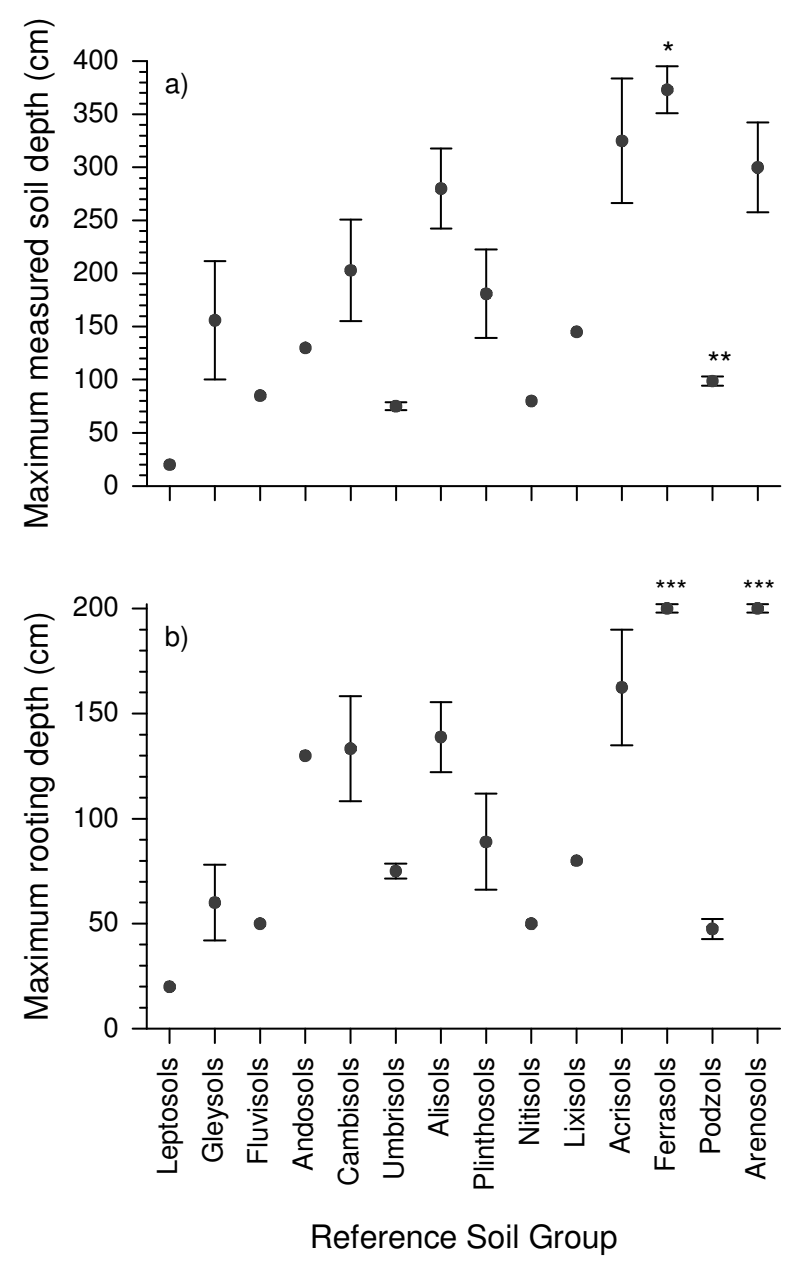

Fig. 22. Changes in soil and root depth in Amazonia following the soil development gradient. (a) maximum soil depth and (b) maximum root depth.

* Ferralsols were often deeper than $4 \mathrm{~m}$, they are often reported to reach depths greater than $10 \mathrm{~m}$.

** Does not reflect actual soil depth as sampling usually stoped at saturated layers.

*** Maximum depth measured was $2.0 \mathrm{~m}$, some roots may be deeper than that.

structure, dynamics and composition (Quesada et al., 2009).

Soil depth (defined here as depth to rock or saprolite contact) is another characteristic associated with pedogenetic stage. In general terms, soils tend to increase in depth following weathering, with Leptosols varying from as little as $0.2 \mathrm{~m}$ deep to more than $4 \mathrm{~m}$ in the Ferralsols (Fig. 22a). Nevertheless, some variation in this trend is expected to occur for soils of sedimentary versus rock origin. This is because soils forming from sediments tend to form deeper soil layers, even when occupying lower taxonomy levels. For example, in young and intermediate age soils derived from crystalline rocks, such as those found at the Guyana and Brazilian shields (Leptosols, Andosols, Nitisols, Lixisols and some Cambisols), were not observed to have depths greater than $1.5 \mathrm{~m}$, but soils which had evolved on sediments (Gleysols, Alisols, Plinthosols and some Cambisols) had maximum depths ranging from 1.5 to $3.5 \mathrm{~m}$ (Fig. 22a). In addition, all 
soils with low to intermediate taxonomic levels (i.e. lower than Acrisols), had a soil depth less than $3 \mathrm{~m}$, independent of rock or sedimentary origin. More weathered soils such as Acrisols and Arenosols have maximum soil depths (MSD) of about $3.5 \mathrm{~m}$ while Ferralsols ranged from about $3.5 \mathrm{~m}$ to more than $4 \mathrm{~m}$ (that being the maximum depth investigated). Maximum soil depth in Podzols was only $1 \mathrm{~m}$ in this study, but this value should be taken with caution once the sampling of these soils was compromised by water saturation and deep soil often collapsed during sampling.

Similarly to maximum soil depth, the maximum depth to which roots can be observed also increases with pedogenetic development (Fig. 22b). However, for most Amazonian soils in this study (particularly the low and intermediate age soils) root maximum depth was shallower than the maximum observed soil depth. For instance, MSD in Gleysols was about $1.5 \mathrm{~m}$ but their associated maximum root depth (MRD) was only $0.6 \mathrm{~m}$. Likewise, MSD for the Acrisols was about $3 \mathrm{~m}$ but their MRD seems limited to around $1.5 \mathrm{~m}$. Roots deeper than $2 \mathrm{~m}$ were only observed in Ferralsols and some Arenosols, with Ferralsols being well known for their very deep root systems (Jipp et al. 1998; Nepstad et al., 1994). Also, we observed that determinants on root depth are most commonly factors other than rock or saprolite contact. We suggest that root depth in Amazon forests is mostly controlled by soil structure (i.e. bulk density and aeration) but with other soil - climate - vegetation interactions such as tree anchorage and water and nutrient availability also important.

Such observations have important implications for ecosystem models since incorrect specifications of rooting depth may give rise to incorrect simulations of the hydrological cycle and general fluxes of heat, $\mathrm{CO}_{2}$ and moisture in Amazonia (Harper et al., 2010). Indeed, although Harper et al. (2010) showed that model parameterization with greater soil depths $(10 \mathrm{~m})$ improved model ability to predict ecosystem function in Amazonia, our results suggests that this may not be a reasonable approach for much of the Amazon Basin. Although the assumption of deep soil layers seems correct for eastern and central portions of Amazonia, particularly under Ferralsols which are notoriously deep rooted soils (Nepstad et al. 1994; Jipp et al. 1998), Table 1 suggests that such soils cover only about $30 \%$ of Amazonia, with the majority of soils, especially in Western Amazonia not capable of supporting root development to and/or function at such depths. In that respect, were not the precipitation in the western part of the Basin substantially greater in amount and with much shorter dry seasons than in the east (Malhi and Wright, 2004), then quite likely evergreen forest could not be sustained there to any great extent. But rather with some form of drought-deciduous forest dominating on the shallow but generally fertile soils occurring closer to the Andes; and as also would be anticipated for any future drier Amazon climate (Lloyd et al. 2009).

\section{Supplementary material related to this article is available online at: http://www.biogeosciences.net/8/1415/2011/ bg-8-1415-2011-supplement.pdf.}

Acknowledgements. We thank all local collaborators in the RAINFOR network for their support during sampling and Tom Bishop (University of Sydney) for providing the S-plus code forming the basis of our fitting of the depth profile functions using R. This work was supported in part by the European Union Fifth Framework Programme as part of CARBONSINK-LBA, part of the European contribution to the Large Scale Biosphere-Atmosphere Experiment in Amazonia (LBA) and recently by the Gordon and Betty Moore Foundation now funding the RAINFOR network. Shiela Lloyd assisted with manuscript preparation.

Edited by: P. Meir

\section{References}

Aubert, G. and Tavernier, R.: The Soils of Africa, in: Soils of the Humid Tropics, National Academy of Science, Washington DC, USA, 17-44, 1972.

Beinroth, F. H.: Some considerations on soil classification in general, and "soil taxonomy" in particular. Departmental Paper Hawaii Agricultural Experiment Station, 49, 18-25, 1981.

Beinroth, F. H.: Some highly weathered soils of Puerto Rico, 1: morphology, formation and classification, Geoderma, 27, 1-73, 1982.

Beinroth, F. H., Uehara, G., and Ikawa, H.: Geomorphic relationships of Oxisols and Ultisols on Kauai, Hawaii, Soil Sci. Soc. Am. J., 38, 128-131, 1974.

Bishop, T. F. A., McBratney, A. B., and Laslett, G. M.: Modelling soil attribute depth functions with equal-area quadratic smoothing splines, Geoderma, 91, 27-45, 1999.

Bravard, S. and Righi, D.: Geochemical differences in an oxisolspodosol toposequence of Amazonia, Brazil, Geoderma, 44, 2942, 1989.

Buol, S. W.: Oxisols, in: Encyclopedia of Soil Science, edited by: Lal, R. and Marcel Dekker, New York, 948-951, 2002.

Buol, S. W. and Eswaran, H.: Oxisols, Adv. Agron., 68, 152-195, 2000.

Buol, S. W., Southard, R. J., McCracken, R. J., and McDaniel, P. A.: Soil Genesis and Classification, 5 Edn., The Iowa State University Press, Ames, Iowa, 494 pp., 2003.

Buurman, P. and Soepraptohardjo, M.: Oxisols and associated soils on ultramafic and felsic volcanic rocks in Indonesia, in: Red Soils in Indonesia, edited by: Buurman, P., Agricultural Research Reports 889, PUDOC, Wageningen, 93-104, 1980.

Chauvel, A., Lucas, Y., and Boulet, R.: On the genesis of the soil mantle of the region of Manaus, Central Amazonia, Brazil, Cell. Mol. Life Sci., 43, 234-241, 1987.

Cotler, H. and Maass, J. M.: Tree management in the northwestern Andean Cordillera of Peru, Mt. Res. Dev., 19, 153-160, 1999.

de Mesquita Filho, M. V. and Torrent, J.: Phosphate sorption as related to mineralogy of a hydrosequence of soils from the Cerrado region (Brazil), Geoderma, 58, 107-123, 1993. 
De Oliveira, J. B. and van den Berg, M.: Relation between the soil units of the FAO-Unesco soil map of the world legend and the soil classes used in the Brazilian surveys, Technical Paper 29, ISRIC, Wageningen, 45 pp., 1996.

Delvaux, B., Herbillon, A. J., and Vielvoye, L.: Characterization of a weathering sequence of soils derived from volcanic ash in Cameroon. Taxonomic, mineralogical and agronomic implications, Geoderma, 45, 375-388, 1989.

Dick, D. P., Goncalves, C. N., Dalmolin, R. S. D., Knicker, H., Klamt, E., Kfgel-Knabner, I., Simoes, M. L., and Martin-Neto, L.: Characteristics of soil organic matter of different Brazilian Ferralsols under native vegetation as a function of soil depth, Geoderma, 124, 319-333, 2005.

Dijkshoorn, J. A., Huting, J. R. M., and Tempel, P.: Update of the 1:5 million Soil and Terrain Database for Latin America and the Caribbean (SOTERLAC; version 2.0), Report 2005/01, ISRIC World Soil Information, Wageningen, 2005.

Do Nascimento, N. R., Bueno, G. T., Fritsch, E., Herbillon, A. J., Allard, T., Melfi, A. J., Astolfo, R., Boucher, H., and Li, Y.: Podzolisation as a deferralitization process: a study of an Acrisol-Podzol sequence derived from Palaeozoic sandstones in the northern upper Amazon Basin, Eur. J. Soil Sci., 55, 523-538, 2004.

Driessen, P., Deckers, J., Spaargaren, O., and Nachtergaele, F.: Lecture notes on the major soils of the world, FAO, Rome, 35-37, 2001.

Dubroeucq, D. and Volkoff, B.: From Oxisols to Spodosols and Histosols: evolution of the soil mantles in the Rio Negro basin (Amazonia), Catena, 32, 245-280, 1998.

FAO: Soil Map of the World. Revised Legend, with corrections, Technical Paper 20, Reprint of World Soil Resources Report 60, FAO, Rome, 1988.

Fittkau, E. J.: Esboço de uma divisão ecolôgica da região amazônica, Proc. Symp. Biol. Trop. Amaz., Florencia y Leticia, 1969, 363-372, 1971.

Fittkau, E. J., Irmler, U., Junt, W. J., Reis, F., and Schmidt, G. W.: Productivity, biomass and population dynamics in Amazonian water bodies, in: Tropical ecological systems, Trends in terrestrial and aquatic and research, edited by: Golley, G. B. and Medina, E., Springer, New York, Berlin, 289-311, 1975.

Fritsch, E., Herbillon, A. J., Do Nascimento, N. R., Grimaldi, M., and Melfi, A. J.: From Plinthic Acrisols to Plinthosols and Gleysols: Iron and groundwater dynamics in the tertiary sediments of the upper Amazon Basin, Eur. J. Soil Sci., 58, 9891006, 2006.

Furch, K. and Klinge, H.: Chemical relationships between vegetation, soil and water in contrasting inundation areas in Amazonia, in: Mineral Nutrients in Tropical Forests and Savanna Ecosystems, Blackwell, Oxford, 1989.

Gaillardet, J., Dupre, B., Allegre, C., and Negrel, P.: Chemical and physical denudation of the Amazon River Basin, Chem. Geol., 142, 141-173, 1997.

Gama, J. R. N. and Kiehl, J. C.: Aluminium influence on plants grown in a Brazilian red-yellow podzolic soil, Revista Brasileira de Ciencia do Solo, 23, 475-482, 1999.

Gee, G. W. and Bauder, J. W.: Particle-size analysis, in: Methods in Soil Analysis, Part 1. Physical and Mineralogical Methods, American Society of Agronomy and Soil Science Society of America, edited by: Klute, A., Madison, Wisconsin, USA,
383-409, 1986.

Glaser, B. and Woods, W. I.: Amazonian dark earths: Exploration in space and time, Springer Verlag, Berlin, 216 pp., 2004.

Harper, A. B., Denning, A. S., Baker, I. T., Branson, M. D., Prihodko, L., and Randall, D. A.: Role of deep soil moisture in modulating climate in the Amazon rainforest, Geophys. Res. Lett., 37, L05802, doi:10.1029/2009GL042302, 2010.

Hartemink, A. E. and Huting, J.: Land cover, extent, and properties of Arenosols in Southern Africa, Arid Land Res. Manag., 22, 134-147, 2008.

Herbillon, A. J.: Mineralogy of Oxisols and oxic materials, in: Soils with Variable Charge, edited by: Theng, B. K. G., New Zealand Society of Soil Science, Lower Hutt, 109-126, 1980.

Herrera, R., Jordan, C. F., Klinge, H., and Medina, E.: Amazon ecosystems: Their structure and functioning with particular emphasis on nutrients, Interciencia, 3, 223-232, 1978.

Hoorn, C., Wesselingh, F. P., ter Steege, H., Bermudez, M. A., Mora, A., Sevink, J., Sanmartín, I., Sanchez-Meseguer, A., Anderson, C. L., Figueiredo, J. P., Jaramillo, C., Riff, D., Negri, F. R., Hooghiemstra, H., Lundberg, J., Stadler, T., Särkinen, T., and Antonelli, A.: Amazonia through time: Andean Uplift, climate change, landscape evolution, and biodiversity, Science, 330, 927-931, 2010.

Horbe, A. M. C., Horbe, M. A., and Suguio, K.: Tropical spodosols in northeastern Amazonas State, Brazil, Geoderma, 119, 55-68, 2004.

Irion, G.: Soil infertility in the Amazonian rain forest, Naturwissenschaften, 65, 515-519, 1978.

Irion, G.: Sedimentation and sediments of Amazonian rivers and evolution of the Amazonian landscape since Pliocene times, in: The Amazon Limnology and Landscape of a Mighty Tropical River and its Basin, edited by: Sioli, H. and Junk, W., Dordecht, 201-214, 1984.

ISRIC (International Soil Reference and Information Centre): Global and national soils and terrain digital databases (SOTER), World Soil Resources Report No. 74, FAO, Rome, 1995.

IUSS (International Union of Soil Science) Working Group WRB: World reference base for soil resources 2006: A framework for international classification, correlation and communication, World Soil Resources Report 103, FAO, Rome, 2006.

EMBRAPA (Empresa Brasileira de Pesquisa Agropecuária). Mapa de solos do Brasil, escala 1:5.000.000. Serviço Nacional de Levantamento e Conservação de Solos, Brasil, 1981.

Jipp, P. H., Nepstad, D. C., Cassel, D. K., and de Carvalho, C. R.: Deep soil moisture storage and transpiration in forests and pastures of seasonally-dry Amazonia, Climate Change, 39, 395412, 1998.

Jordan, C. F.: Are process rates higher in tropical forest ecosystems? in: Mineral Nutrients in Tropical Forests and Savanna Ecosystems, edited by: Proctor, J., Blackwell, Oxford, 1989.

Jordan, C. F. and Herrera, R.: Tropical rain forests: are nutrients really critical? Am. Nat., 117, 167-180, 1981.

Kronberg, B. I., Franco, J. R., Benchimol, R. E., Hazenberg, G., Doherty, W. and VanderVoet, A.: Geochemical variations in Solimoes formation sediments (Acre basin, Western Amazonia), Acta Amazonica, 19, 319-333, 1989.

Kronberg, B. I., Fralick, P. W., and Benchimol, R. E.: Late quaternary sedimentation and paleohydrology in the Acre foreland basin SW Amazonia, Basin Res., 10, 311-323, 1998. 
Lathwell, D. J. and Grove, T. L.: Soil-Plant Relationships in the Tropics, Ann. Rev. Ecol. Syst., 17, 1-16, 1986.

Lehmann, J., Kern, D. C., Glaser, B., and Woods, W. I.: Amazonian dark earths, origin, properties, management, Kluwer Academic Publishers, Netherlands, 505 pp., 2003.

Lepsch, I. F. and Buol, S. W.: Investigations in an Oxisol-Ultisol Toposequence in S. Paulo State, Brazil, Soil Sci. Soc. Am. J., 38, 491-496, 1974.

Lima, H. N., Mello, J. W. V., Schaefer, C. E. G. R., Ker, J. C., and Lima, A. M. N.: Mineralogia e quimica de tres solos de uma topossequencia da bacia sedimentar do Alto Solimoes, Amazonia Ocidental, Rev. Bras. Cienc. Solo, 30, 59-68, 2006.

Lips, J. M. and Duivenvoorden, J. F.: Regional patterns of well drained upland soil differentiation in the middle Caquetá basin of Colombian Amazonia, Geoderma, 72, 219-257, 1996.

Lloyd J., Goulden, M., Ometto, J. P., Fyllas, N. M., Quesada, C. A., and Patiño, S.: Ecophysiologuy of forest and savanna vegetation, in: Amazonia and Climate Change, edited by: Keller, M., Gash, J., and Silva Dias, P., American Geophysical Union, Washington DC, 463-484, 2009b.

Lucas, Y.: Biogeoquímica em ambiente equatorial: exemplo dos sistemas Latossolos-Podzóis da Amazônia, in: Cong. Intern. Geoq, 4, Anais, 9-12, 1997.

Lucas, Y., Chauvel, A., Boulet, R., Ranzani, G., and Scatolini, F.: Transição latossolos-podzóis sobre a formação barreiras na região de Manaus, Amazônia, Rev. Bras. Cienc. Solo, 8, 325335, 1984.

Malhi, Y. and Wright, J.: Spatial patterns and recent trends in the climate of tropical rainforest regions, Phil. Trans. R. Soc. Lond. B., 359, 311-329, 2004.

Marbut, C. F. and Manifold, C. B.: The soils of the Amazon basin in relation to their agricultural possibilities, Geogr. Rev., 15, 617643, 1926.

Marques, J. J. G. S. M., Teixeira, W. G., Schulze, D. G., and Curi, N.: Mineralogy of soils with unusually high exchangeable Al from the western Amazon Region, Clay Mineralogy, 37, 651661, 2002.

Medina, E. and Cuevas, E.: Patterns of nutrient accumulation and release in Amazonian forests of the upper Rio Negro Basin, in: Mineral Nutrients in Tropical Forests and Savanna Ecosystems, edited by: Proctor, J., Blackwell, Oxford, 1989.

Melo, V. F., Schaefer, C. E. G. R., and Uchôa, S. C. P.: Indian land use in the Raposa-Serra do Sol Reserve, Roraima, Amazonia, Brazil: Physical and chemical attributes of a soil catena developed from mafic rocks under shifting cultivation, Catena, 80, 95-105, 2010.

Moreira, F. M. S., Nóbrega, R. S. A., Jesus, E. C., Ferreira, D. F., and Pérez, D. V.: Differentiation in the fertility of Inceptisols as related to land use in the upper Solimões river region, western Amazon, Sci. Total Environ., 408, 349-355, 2009.

Nepstad, D. C., de Carvalho, C. R., Davidson, E. A., Jipp, P. H., Lefebvre, P. A., Negreiros, da Silva, G. H. D., Stone, E. T. A., Trumbore, S. E., and Viera, S.: The role of deep roots in the hydrological and carbon cycles of Amazonian forests and pastures, Nature, 372, 666-669, doi:10.1038/372666a0, 1994.

Nelson, D. W. and Sommers, L. E.: Total carbon and total nitrogen, in: Methods of Soil Analysis: Part 3 - Chemical Methods, SSSA Book Series No 5, SSSA and ASA, edited by: Sparks, D. L., Madison, WI, 961-1010, 1996.
Nicou, R.: Contribution to the study and improvement of the porosity of the sandy and clayed-sandy soils in the dry tropical area, Agricultural consequences, Agron. Trop., 29, 1100-1127, 1974.

Nicou, R.: The problem of caking with the drying out of sandy and sandy clay soils in the arid tropical zone, Agron. Trop., 30, 325343, 1975.

Nicou, R. and Charreau, C.: Mechanical impedance to land preparation as a constraint to food production in the tropics (with special reference to fine sandy soils in West Africa), in: Soil Related Constraints to Food Production in the Tropics, IRRI, Manila, Philippines, 371-388, 1980.

Osher, L. J. and Buol, S. W.: Relationship of soil properties to parent material and landscape position in eastern Madre de Dios, Peru, Geoderma, 83, 143-166, 1998.

Pella, E.: Elemental organic analysis, Part 2, State of the art, American Laboratory, 22, 28-32, 1990.

Pleysier, J. L. and Juo, A. S. R.: A single-extraction method using silver-thiourea for measuring exchangeable cations and effective CEC in soils with variable charges, Soil Sci., 129, 205-211, 1980.

Posey, D. A. and Balick, M. J.: Human impacts on Amazonia: The role of traditional ecological knowledge in conservation and development, Columbia University Press, New York. 367 pp., 2006.

Qafoku, N. P., Van Ranst, E., Noble, A., and Baert, G.: Variable Charge Soils: Their Mineralogy, Chemistry and Management, Adv. Agron., 84, 160-217, 2004.

Quesada, C. A., Lloyd, J., Schwarz, M., Baker, T. R., Phillips, O. L., Patiño, S., Czimczik, C., Hodnett, M. G., Herrera, R., Arneth, A., Lloyd, G., Malhi, Y., Dezzeo, N., Luizão, F. J., Santos, A. J. B., Schmerler, J., Arroyo, L., Silveira, M., Priante Filho, N., Jiménez, E. M., Paiva, R., Vieira, I., Neill, D. A., Silva, N., Peñuela, M. C., Monteagudo, A., Vásquez, R., Prieto, A., Rudas, A., Almeida, S., Higuchi, N., Lezama, A. T., López-González, G., Peacock, J., Fyllas, N. M., Alvarez Dávila, E., Erwin, T., di Fiore, A., Chao, K. J., Honorio, E., Killeen, T., Peña Cruz, A., Pitman, N., Núñez Vargas, P., Salomão, R., Terborgh, J., and Ramírez, H.: Regional and large-scale patterns in Amazon forest structure and function are mediated by variations in soil physical and chemical properties, Biogeosciences Discuss., 6, 39934057, doi:10.5194/bgd-6-3993-2009, 2009.

Quesada, C. A., Lloyd, J., Schwarz, M., Patiño, S., Baker, T. R., Czimczik, C., Fyllas, N. M., Martinelli, L., Nardoto, G. B., Schmerler, J., Santos, A. J. B., Hodnett, M. G., Herrera, R., Luizão, F. J., Arneth, A., Lloyd, G., Dezzeo, N., Hilke, I., Kuhlmann, I., Raessler, M., Brand, W. A., Geilmann, H., Moraes Filho, J. O., Carvalho, F. P., Araujo Filho, R. N., Chaves, J. E., Cruz Junior, O. F., Pimentel, T. P., and Paiva, R.: Variations in chemical and physical properties of Amazon forest soils in relation to their genesis, Biogeosciences, 7, 1515-1541, doi:10.5194/bg-7-15152010, 2010.

RADAMBRASIL: Levantamento dos Recursos Naturais, Ministério de Minas e Energia, Departamento Nacional de Produção Mineral, Rio de Janeiro, 1978.

Reatto, A., Correia, J. R., and Spera, S. T.: Solos do Bioma Cerrado: Aspectos pedologicos, in: Cerrado ambiente e Flora. Planaltina, edited by: Sano, S. M. and Almeida, S. P., EMBRAPA CPAC, 47-86, 1998.

Richter, D. D. and Babbar, L. I.: Soil diversity in the tropics, Adv. 
Ecol. Res., 21, 315-389, 1991.

Saatchi S. S., Steinenger, M., Tucker, C. J., Nelson, B., and Simard, M.: $1 \mathrm{~km}$ Land Cover and Wetlands Maps of the Amazon Basin. Data set available from Oak Ridge National Laboratory Distributed Active Archive Center, Oak Ridge, Tennessee, U.S.A.,, 2008.

Sanchez, P. A.: Properties and Management of Soils in the Tropics, John Wiley \& Sons, New York, 618 pp., 1976.

Sanchez, P. A. and Buol, S. W.: Properties of some soils of the upper Amazon Basin of Peru, Soil Sci. Soc. Am. J., 38, 117-121, 1974.

Sanchez, P. A. and Buol, S. W.: Soils of the tropics and the world food crisis, Science, 188, 598-603, 1975.

Schad, P., Haussermann, U., Ferber, P., and Rinneberg, K.: Phaeozems or Ferralsols? Low-activity clay soils with mollic horizons in Bolivian tropical lowlands, European Soil Bureau Research Report \#7, Publications of the European Communities, Luxembourg, 2001.

Shoji, S., Nanzyo, M., and Dahlgren, R.: Volcanic Ash Soils: Genesis, Properties and Utlization, Developments in Soil Science 21, Elsevier, 288, New York, USA. 1993.

Schobbenhaus, C. and Bellizzia, A. (coord.): Geological Map of South America, 1:5,000,000, CGMW-CPRM-DNPM-UNESCO, Paris, 2001.

Smeck, N. E.: Phosphorus dynamics in soils and landscapes, Geoderma, 36, 185-199, 1985.

Soares-Filho, B. S., Nepstad, D. C., Curran, L. M., Cerqueira, G. C., Garcia, R. A., Ramos, C. A., Voll, E., McDonald, E., Lefebvre, P., and Schlesinger, P.: Modelling conservation in the Amazon basin, Nature, 440, 520-523, 2006.

Sombroek, W. G.: A reconnaissance of the soils of the Brazilian Amazon region, Centre for Agricultural Publications and Documentation, Wageningen, 1966.

Sombroek, W. G.: Soils of the Amazon Region,in: The Amazon: Limnology and Landscape Ecology of a Mighty Tropical River and its Basin, edited by: Sioli, H. and Junk, W., Dordrecht, 521535,1984

Sombroek, W. G.: Amazon landforms and soils in relation to biological diversity, Acta Amazonica, 30, 81-100, 2000.
Sombroek, W. G. and Camargo, M. N.: Groundwater laterites and ironstone soils in Brazil, with examples from the Amazon region, in: Proceedings of the Second International Seminar on Laterisation Processes, edited by: Melfi, A. J. and Carvalho, A., IAG, Sao Paulo, Brazil, 541-552, 1983.

Thomas, M. F.: Tropical Geomorphology, The McMillan Press, London, 331 pp, 1974.

Uehara, G. and Gilman, G.: The Mineralogy, Chemistry, and Physics of Tropical Soils with Variable Charge Clays, Westview Press, Boulder, Colorado, 1981.

Van Reeuwijk, L. P.: Procedures for soil analysis. International Soil Reference Information Centre, ISRIC, sixth edition, Wageningen, Netherlands, 120 pp., 2002.

van Wambeke, A.: Properties and potential of soils in the Amazon Basin, Interciencia, 43, 233-241, 1978.

van Wambeke, A.: Soils of the Tropics - Properties and Appraisal, McGraw-Hill, New York, 1992.

van Wambeke, A., Eswaran, H., Herbillon, A. J., and Comera, J.: Oxisols, edited by: Wilding, L. P., Smeck, N. E. and Hall, G. F., in: Pedogenesis and Soil Taxonomy: The Soil Orders, Elsevier, Amsterdam, 325-354, 1983.

Vitousek, P. M. and Sanford, R. L.: Nutrient cycling in moist tropical forest, Annu. Rev. Ecol. Syst., 17, 137-167, 1986.

Went, F. W. and Stark, N.: Mycorrhiza, Bioscience, 18, 1035-1039, 1968.

West, L. T., Beinroth, F. H., Summer, M. F., and Kang, B. T.: U1tisols: characteristics and impacts on society, Adv. Agron., 63, 179-236, 1998.

Wilding, L. P., Drees, L. R., and Nordt, L. C.: Spatial variability: Enhancing the mean estimate of organic and inorganic carbon in a sampling unit, in: Assessment Methods for Soil Carbon, edited by: Lal, R., Kimble, J. M. Follett, R. F., and Stewart, B. A., CRC Press, 69-86, Florida, USA, 1983.

Zinn, Y. L., Lal, R., Bigham, J. M., and Resck, D. V. S.: Edaphic controls on soil organic carbon retention in the Brazilian Cerrado: Texture and mineralogy, Soil Sci. Soc. Am. J., 71, 1204 1214, 2007. 